\title{
Caffeine-Sensitive Calcium Stores Regulate Synaptic Transmission from Retinal Rod Photoreceptors
}

\author{
David Krizaj,, Jian-Xin Bao, ${ }^{1}$ Yvonne Schmitz,, ${ }^{2}$ Paul Witkovsky, ${ }^{2,3}$ and David R. Copenhagen ${ }^{1}$ \\ ${ }^{1}$ Departments of Ophthalmology and Physiology, University of California at San Francisco School of Medicine, \\ San Francisco, California 94143-0730, and Departments of 2 Physiology and Neuroscience and ${ }^{3}$ Ophthalmology, \\ New York University Medical Center, New York, New York 10016
}

We investigated the role of caffeine-sensitive intracellular stores in regulating intracellular calcium $\left(\left[\mathrm{Ca}^{2+}\right]_{\mathrm{i}}\right)$ and glutamatergic synaptic transmission from rod photoreceptors. Caffeine transiently elevated and then markedly depressed $\left[\mathrm{Ca}^{2+}\right]_{\mathrm{i}}$ to below prestimulus levels in rod inner segments and synaptic terminals. Concomitant with the depression was a reduction of glutamate release and a hyperpolarization of horizontal cells, neurons postsynaptic to rods. Caffeine did not affect the rods' membrane potentials indicating that caffeine likely acted via some mechanism(s) other than a voltage-dependent deactivation of the calcium channels. Most of caffeine's depressive action on $\left[\mathrm{Ca}^{2+}\right]_{\mathrm{i}}$, on glutamate release, and on $I_{\mathrm{Ca}}$ in rods can be attributed to calcium release from stores: (1) caffeine's actions on $\left[\mathrm{Ca}^{2+}\right]_{i}$ and $I_{\mathrm{Ca}}$ were reduced by intracellular BAPTA and barium substitution for calcium, (2) other nonxanthine

It is now generally recognized that intracellular calcium concentration $\left(\left[\mathrm{Ca}^{2+}\right]_{\mathrm{i}}\right)$ is an important regulator of neurotransmitter release. Extensive studies have delineated a role for calcium influx in gating transmitter release (Katz and Miledi, 1969; Matthews, 1997; Neher, 1998). Much less study has been directed at a possible role of intracellular calcium stores in exocytosis, particularly in glutamatergic neurons. In chromaffin cells, $\mathrm{Ca}^{2+}$ released from caffeine-sensitive intracellular storage compartments can both enhance and reduce exocytosis of catecholamines. The stimulation of exocytosis by caffeine may occur in the absence of extracellular calcium (Cheek et al., 1990). However, caffeine treatment can also reduce the size of depolarization-evoked release of catecholamines from these same cells (Lara et al., 1997). On the basis of the finding that caffeine reduced the depolarization-evoked rises of $\left[\mathrm{Ca}^{2+}\right]_{\mathrm{i}}$ in bullfrog neurons, Friel and Tsien (1992) articulated the hypothesis that caffeine-induced depletion of stores stimulated uptake back into these compartments and that this sequestration acted as a sink for incoming calcium. Cseresnyes et al. (1997) concluded that in frog sympa-

\footnotetext{
Received Aug. 19, 1998; revised June 7, 1999; accepted June 10, 1999.

This work was supported by the National Institutes of Health (D.R.C. and P.W.), Research to Prevent Blindness (D.R.C. and P.W.), the Hoffritz Foundation (P.W.), an Association for Research in Vision and Ophthalmology / CIBA Vision Corporation award (D.K.), and the Deutsche Forschungsgemeinschaft (Y.S.). Additional support was provided by That Man May See, Inc. We thank Drs. Fred Rieke and Richard Lewis for valuable comments on previous versions of this manuscript.

Correspondence should be addressed to Dr. David Krizaj, Department of Ophthalmology, University of California at San Francisco School of Medicine, Box 0730, Room K-140, 10 Kirkham Street, San Francisco, CA 94143-0730.

Dr. Schmitz's present address: Department of Neurology, Columbia University, New York, NY 10032.

Copyright (C) 1999 Society for Neuroscience 0270-6474/99/197249-13\$05.00/0
}

store-releasing compounds, such as thymol and chlorocresol, also depressed $\left[\mathrm{Ca}^{2+}\right]_{i}$, and (3) the magnitude of $\left[\mathrm{Ca}^{2+}\right]_{i}$ depression depended on basal $\left[\mathrm{Ca}^{2+}\right]_{i}$ before caffeine. We propose that caffeine-released calcium reduces $I_{\mathrm{Ca}}$ in rods by an as yet unidentified intracellular signaling mechanism. To account for the depression of $\left[\mathrm{Ca}^{2+}\right]_{i}$ below rest levels and the increased fall rate of $\left[\mathrm{Ca}^{2+}\right]_{i}$ with higher basal calcium, we also propose that caffeine-evoked calcium release from stores activates a calcium transporter that, via sequestration into stores or extrusion, lowers $\left[\mathrm{Ca}^{2+}\right]_{i}$ and suppresses glutamate release. The effects of store-released calcium reported here operate at physiological calcium concentrations, supporting a role in regulating synaptic signaling in vivo.

Key words: photoreceptor; rod; calcium; caffeine; intracellular calcium stores; glutamate release thetic ganglion neurons there is a release-activated calcium transport (RACT) that significantly increases sequestration into stores when calcium is released from caffeine-sensitive compartments. When activated, RACT transports calcium at rates 1.6 and 4 times faster than the conventional sarcoplasmic-endoplasmic calcium ATPases (SERCA) and the plasma membrane extrusion pumps, respectively. This indicates that RACT can play a significant role in controlling $\left[\mathrm{Ca}^{2+}\right]_{\mathrm{i}}$, and possibly exocytosis as well. In this present study we used the rod-horizontal cell synapse of the amphibian retina to examine the possibility that caffeinesensitive $\mathrm{Ca}^{2+}$ stores contribute to the regulation of glutamate exocytosis.

A hallmark feature of synaptic transmission at the photoreceptor and bipolar cell synapses of the retina is the continuous release of glutamate. It is generally accepted that the release from rods is directly controlled by an influx of $\mathrm{Ca}^{2+}$, predominantly through L-type calcium channels located in inner segments and synaptic terminals of these cells (Copenhagen and Jahr, 1989; Rieke and Schwartz, 1996; Schmitz and Witkovsky, 1997; Witkovsky et al., 1997). In general, caffeine-sensitive stores are localized to smooth endoplasmic reticulum (ER) (Golovina and Blaustein, 1997; Meldolesi and Pozzan, 1998), an intracellular compartment widely distributed throughout the cell body, dendritic trees, and synaptic terminals of neurons (Walton et al., 1991; Krijnse-Locker et al., 1995). Although there are no reports of caffeine-sensitive stores in photoreceptors, cisternae of smooth ER have been noted in synaptic nerve terminals of photoreceptors (Mercurio and Holtzman, 1982; Ungar et al., 1984).

We studied the effects of caffeine on both presynaptic and postsynaptic cells at the photoreceptor synapse. We investigated 
the effects of caffeine on $\left[\mathrm{Ca}^{2+}\right]_{\mathrm{i}}$ in rods using fura-2, on L-type calcium currents in rods using whole-cell recording methods, on rod and horizontal cell membrane potentials using microelectrode techniques, and on the release of endogenous glutamate using a newly developed preparation consisting of a sheet of photoreceptors separated from the rest of the retina (Cahill and Besharse, 1992; Schmitz and Witkovsky, 1996). Our data strongly suggest that calcium release from caffeine-sensitive calcium stores can modulate synaptic transmission from these glutamatergic neurons.

Parts of this study have been published previously in abstract form (Krizaj et al., 1997).

\section{MATERIALS AND METHODS}

The experiments were performed on rod photoreceptors from two amphibian species: the clawed frog (Xenopus laevis) and the tiger salamander (Ambystoma tigrinum). All imaging experiments were performed on salamander photoreceptors because of their large size and experimental tractability; we used the Xenopus retina because it can be used as a "reduced preparation" to study glutamate release (see below) (Schmitz and Witkovsky, 1996). Intracellular recording was performed on both Xenopus and Ambystoma horizontal cells (HC). We found no significant species differences in relation to the light-evoked responses or membrane potential of HCs when exposed to caffeine.

Preparation of isolated cells. Larval stage tiger salamanders were decapitated and pithed. Retinas were dissected at room temperature (20$\left.22^{\circ} \mathrm{C}\right)$ in room light, incubated on a shaker in $0 \mathrm{Ca}^{2+}$ and papain $(7 \mathrm{U} / \mathrm{ml}$; Worthington, Freehold, NJ) saline for $25 \mathrm{~min}$, and triturated with a BSA-coated Pasteur pipette. The outer segments of many rods were shorn during the isolation procedure, resulting in the absence of the dark current and hyperpolarization of their membrane potentials. Dissociated cells were kept at $4^{\circ} \mathrm{C}$ in $80 \% \mathrm{~L}-15$ medium supplemented with $10 \mathrm{~mm}$ HEPES, $20 \mathrm{~mm}$ glucose, $1 \mathrm{~mm}$ pyruvic acid, $1 \mathrm{mg} / \mathrm{ml}$ bovine serum albumin, and $1 \mu \mathrm{l} / \mathrm{ml}$ Liquid Media Supplement containing transferrin and selenium (Sigma, St. Louis, MO). Cells were plated onto acidcleaned glass coverslips coated with $\mathrm{IgG}$ and/or IgM (Jackson ImmunoResearch, West Grove, PA) and the Sal-1 antibody [a kind gift from Dr. Peter MacLeish (MacLeish et al., 1983)]. The control saline solution contained (in mM): $97 \mathrm{NaCl}, 2 \mathrm{KCl}, 2 \mathrm{CaCl}_{2}, 2 \mathrm{MgCl}_{2}, 10$ HEPES, 20 glucose, 1 pyruvic acid, 0.3 ascorbic acid, and 1 glutathione at 240 mOsm. pH was adjusted to 7.6 with $\mathrm{NaOH}$. In the high $(20 \mathrm{~mm})$ potassium saline the concentration of $\mathrm{NaCl}$ was correspondingly reduced. The volume around cells was superfused through either a Y-tube mechanism in which solution exchange was completed within $10 \mathrm{sec}$ or a multibarrel quartz perfusion system that allowed solution exchange within $100 \mathrm{msec}$.

$\left[\mathrm{Ca}^{2+}\right]$ measurement and image acquisition. These measurements are described in more detail elsewhere (Krizaj and Copenhagen, 1998). Briefly, photoreceptors were loaded for 10 min with 3-5 $\mu \mathrm{M}$ fura-2 AM (Molecular Probes, Eugene, OR) supplemented with $0.005 \%$ Pluronic F-127 in L-15 and then washed for $20 \mathrm{~min}$ in L-15. The fluorescence signals were acquired at $0.3-1 \mathrm{~Hz}$ by a cooled 12 -bit digital CCD camera (PXL; Photometrics, Tucson, AZ) controlled by commercial software (Metafluor; Universal Imaging Corporation, West Chester, PA). Ratios between the 340 and $380 \mathrm{~nm}$ excitation wavelengths were calculated after subtraction of the background fluorescence. Free $\mathrm{Ca}^{2+}$ levels were calibrated in vivo with $10 \mu \mathrm{M}$ ionomycin using the standard relationship developed by Grzynkiewicz et al. (1985). The $K_{d}$ values for $\mathrm{Ca}^{2+}(224$ $\mathrm{nM})$ and $\mathrm{Ba}^{2+}(780 \mathrm{nM})$ binding to fura-2 were taken from the literature (Grzynkiewicz et al., 1985; Schilling et al., 1989; Neher, 1995). The actual calcium concentrations should be considered estimates, because a standardized value for the $K_{d}$ of fura- 2 was used throughout these experiments. Most measurements were taken in a region encompassing most of the inner segment of isolated rods. Loss of synaptic terminals during dissociation and low signal/noise ratios made it difficult to test routinely every protocol on the terminals. The waveforms of the transient elevations and depressions of calcium were not discernibly different from those in the inner segments. The lower signal/noise ratio prevented us from quantitatively assessing whether the responses were faster in the terminals, as we had reported previously for potassium-evoked rises of calcium (Krizaj and Copenhagen, 1998).

Patch-clamp recording. Recording electrodes were pulled in four steps on a horizontal pipette puller (P97; Sutter Instruments, Novato, CA) from $1.7 \mathrm{~mm}$ borosilicate capillary glass (TW 150F; World Precision Instruments, Sarasota, FL). Electrodes were filled with (in $\mathrm{mM}$ ): $75 \mathrm{Cs}$ $\mathrm{MeSO}_{4}, 5$ EGTA, 30 HEPES, $0.5 \mathrm{CaCl}_{2}, 2 \mathrm{Mg}$-ATP, $0.5 \mathrm{Na}_{3} \mathrm{GTP}$, and 20 TEA-Cl, with $\mathrm{pH}$ adjusted to 7.5 with $\mathrm{CsOH}$. The electrode resistance was $10-20 \mathrm{M} \Omega$. The extracellular solution contained (in $\mathrm{mM}$ ): 55 $\mathrm{NaCl}, 2.5 \mathrm{KCl}, 10 \mathrm{CaCl}_{2}, 1 \mathrm{MgCl}_{2}, 8$ glucose, $10 \mathrm{HEPES}$, and 30 TEA-Cl, with $\mathrm{pH}$ buffered to 7.6 with $\mathrm{NaOH}$. In some experiments, 10 $\mathrm{mM} \mathrm{CaCl}_{2}$ was replaced by $10 \mathrm{mM} \mathrm{BaCl} 2$. Seal resistance ranged from 1 to $20 \mathrm{G} \Omega$. Series resistances were typically $4-12 \mathrm{M} \Omega$. The membrane current was measured with an Axopatch 2-D amplifier (Axon Instruments, Foster City, CA). Capacitance currents were canceled electronically. Current records were low-pass filtered at $2 \mathrm{kHz}(-3 \mathrm{~dB})$ and digitized at $5 \times$ the filter cutoff frequency. Data were acquired via an analog-to-digital interface (Indec Systems, Sunnyvale, CA). Junction potentials were $1-2 \mathrm{mV}$, as measured using a low-resistance $3 \mathrm{M} \mathrm{KCl}$ reference electrode in the bath; membrane potentials were not corrected for junction potentials. Leak subtraction was performed on whole-cell currents as follows. $\mathrm{Ca}^{2+}$ currents were blocked by adding $100 \mu \mathrm{M} \mathrm{Cd}^{2+}$, and the remaining leak currents were subtracted from the equivalent experimental records from the same cell. The leak currents usually were obtained immediately after each set of experimental records. The perforated-patch recordings were performed as described above, except that the electrode was filled with $2 \mathrm{ng} \cdot \mathrm{ml}^{-1}$ gramicidin.

Rods were held at $-70 \mathrm{mV}$. In most experiments, $\mathrm{Ca}^{2+}$ currents were induced by depolarizing the cells with voltage ramps $(-70$ to $+50 \mathrm{mV})$ scanned at a rate of $1.02 \mathrm{~V} / \mathrm{sec}$. Ramps were given at $20 \mathrm{sec}$ intervals throughout the experiments, and the drugs under study were applied onto cells after $\mathrm{Ca}^{2+}$ currents stabilized, which typically occurred within a few minutes after break-in. Solutions were exchanged via a gravitydriven multibarrel microperfusion system positioned within $1 \mathrm{~mm}$ of the tested cell.

The percentage inhibition of $\mathrm{Ca}^{2+}$ currents was expressed as $[1-$ $I_{\mathrm{Ca}}($ test $) / I_{\mathrm{Ca}}($ control) $] \times 100$. Cadmium-subtracted currents were used, whenever possible, to calculate the peak amplitude. Student's $t$ tests were performed for paired or unpaired groups, whereas one-way ANOVA was done for three or more groups.

Intracellular recording. Eyecups were prepared as described previously (Krizaj et al., 1994). Microelectrodes were backfilled with 4 m potassium acetate and had an average resistance of 150-200 $\mathrm{M} \Omega$. After isolation in room light, the eyecups were dark adapted in the superfusion chamber for $>1 \mathrm{hr}$ before recording. The eyecups were superfused continuously at $1.5 \mathrm{ml} / \mathrm{min}$ and stimulated with diff use $200 \mathrm{msec}$ steps of light emitted by a green light-emitting diode $\left(\lambda_{\max }=567 \mathrm{~nm}\right)$. Light intensity was controlled by a neutral density wedge. Data were stored on digital tape for off-line analysis with SPIKE software (Modular Instruments, Taunton, MA). Isolated cells were obtained as described above and impaled with borosilicate microelectrodes attached to a motorized manipulator (MP285; Sutter Instruments). Under these conditions photoreceptors are hyperpolarized to -55 to $-65 \mathrm{mV}$ (Bader et al., 1979; Barnes and Hille, 1989) (D. Krizaj and D. R. Copenhagen, unpublished observations) that is close to the light-evoked plateau potentials measured in intact rods in vivo (Fain, 1976; Witkovsky et al., 1997). Because we were interested in the modulation of glutamate release, whose magnitude is higher at more depolarized membrane potentials, we usually depolarized the test rod by elevating extracellular $\left[\mathrm{K}^{+}\right]$. In isolated rods, $20 \mathrm{~mm} \mathrm{KCl} \mathrm{raised} \mathrm{Vm}$ from approximately $-60 \mathrm{mV}$ to approximately $-40 \mathrm{mV}$, a value that is close to dark potentials recorded in intact rods.

Glutamate release. The preparation of the reduced retina was performed as described previously (Schmitz and Witkovsky, 1996). Briefly, the cornea, the inner ring of the iris, and the lens were removed, and the eyecup was flushed successively with $0.5 \%$ Triton X-100 in distilled water, distilled water alone, and culture medium. After $\sim 1 \mathrm{hr}$ of incubation in culture medium, the retina split apart in the inner nuclear layer, permitting the inner retinal layers to be removed with fine forceps and thereby preserving a laminar sheet of photoreceptor cells. The preservation of physiological function in this preparation is documented in Schmitz and Witkovsky (1996) and Witkovsky et al. (1997).

All experiments were done in room light $\left(40 \mu \mathrm{W} / \mathrm{cm}^{2}\right)$ in the plane of the retina. The reduced retinas were maintained in aerated chambers $\left(\begin{array}{lll}95 \% & \mathrm{O}_{2} / 5 \% & \mathrm{CO}_{2}\end{array}\right)$ and superfused at $1 \mathrm{ml} / \mathrm{hr}$ with culture medium containing (in mM): $82 \mathrm{NaCl}, 2 \mathrm{KCl}, 1.8 \mathrm{CaCl}_{2}, 1 \mathrm{MgCl}_{2}, 35 \mathrm{NaHCO}_{3}$, and $1 \mathrm{NaH}_{2} \mathrm{PO}_{4}, \mathrm{pH}$ 7.55. The basic salt medium was supplemented with $5 \mathrm{~mm}$ glucose, $100 \mu \mathrm{M}$ ascorbic acid, and a mixture of 14 amino acids including $5 \mu \mathrm{M}$ glutamine. Dihydrokainate $(2 \mathrm{mM})$ was added to all media 
A

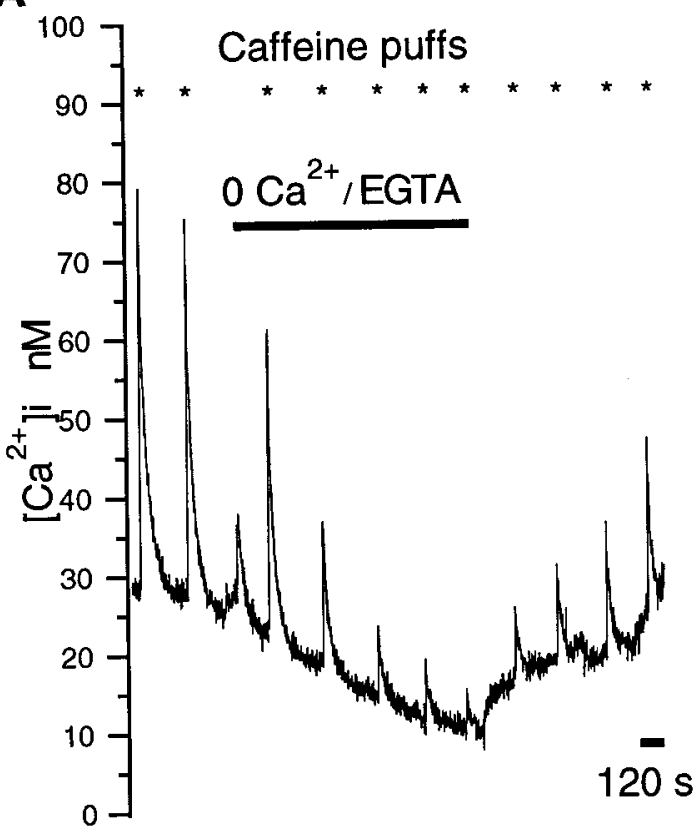

B

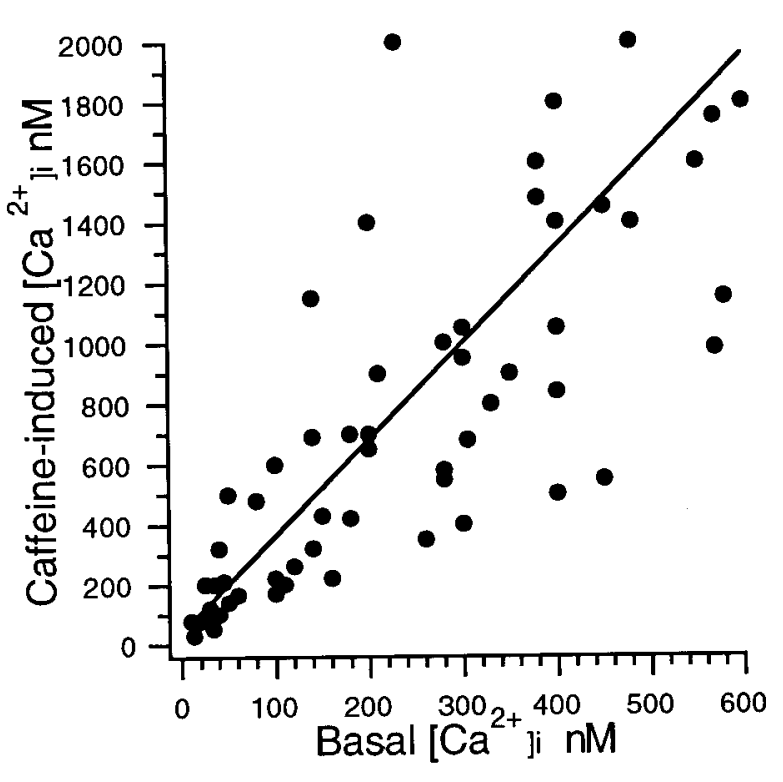

Figure 1. Caffeine evokes a transient increase of $\left[\mathrm{Ca}^{2+}\right]_{\mathrm{i}}$ in rods. $A$, Responses of $\left[\mathrm{Ca}^{2+}\right]_{\mathrm{i}}$ to brief puffs of caffeine $(50 \mathrm{~mm}$ in the pipette; indicated by the stars). Isolated cells were perfused continuously first with control saline containing $2 \mathrm{mM} \mathrm{KCl}$ and $2.0 \mathrm{~mm} \mathrm{Ca}^{2+}$, then with calcium-free $\left(0 \mathrm{Ca}^{2+}+\right.$ EGTA) saline (indicated by the horizontal bar), and then with control. Caffeine-induced transients became progressively smaller in calcium-free saline but grew progressively larger after return to control, consistent with a rundown and then replenishment of caffeine-sensitive stores in the absence and reestablishment, respectively, of calcium influx from outside the rod. $B$, Amplitude of the caffeine-induced transient peaks of $\left[\mathrm{Ca}^{2+}\right]_{\mathrm{i}}$ as a function of prestimulus calcium concentration. Peak magnitude was correlated positively with basal concentration, suggesting that the caffeine-sensitive stores were more completely filled at higher $\left[\mathrm{Ca}^{2+}\right]_{\mathrm{i}}\left(n=70\right.$ measurements in 62 different cells; data summed with $\left[\mathrm{K}^{+}\right]_{\mathrm{o}}$ ranging from 2 to $\left.45 \mathrm{mM}\right)$.

to reduce glutamate reuptake. Two-position valves permitted a rapid switch from control to test solution. Test solutions flowed for at least 30 min before samples, each representing $5 \mathrm{~min}$ of perfusion, were collected.

The glutamate content was analyzed by the method of Fosse et al. (1986) that uses glutamate dehydrogenase coupled via FMN reductase to bacterial luciferase. The resulting light production was measured by a luminometer (Monolight 2010; Analytical Luminescence Lab, San Diego, CA). L-glutamate standards were prepared in control and test solutions. For statistical analysis, ANOVA with the subsequent Tukey test was used. All data were normalized to the glutamate released during superfusion with control saline containing $2 \mathrm{mM} \mathrm{KCl}$.

Chemicals. Nifedipine (Sigma), ryanodine (9,21-didehydro-ryanodine: ryanodine ratio of 60:40; Research Biochemicals, Natick, MA), and 1,2-bis(2-aminophenoxy)ethane- $N, N, N^{\prime}, N^{\prime}$-tetra-acetic acid (BAPTA) AM (Molecular Probes) were dissolved in DMSO. BAPTA AM was made as a $1 \mathrm{~mm}$ stock and was diluted to 5-20 $\mu \mathrm{M}$ before the experiment. Dilutions were made fresh with final concentrations of DMSO $<0.001 \%$. The free-acid form of BAPTA used in whole-cell experiments was dissolved directly into the internal pipette solution. 4-Chloro- $m$-cresol [4-chloro-3-methylphenol (4-CmC)] was obtained from Aldrich (Milwaukee, WI); thymol, glutamate dehydrogenase, gramicidin, and luciferase were from Sigma; and FMN reductase was obtained from Boehringer Mannheim (Indianapolis, IN).

\section{RESULTS}

Caffeine is a xanthine that releases $\left[\mathrm{Ca}^{2+}\right]_{\mathrm{i}}$ from intracellular stores by increasing the affinity of the ryanodine receptor for cytoplasmic $\mathrm{Ca}^{2+}$ (Pozzan et al., 1994; Hernandez-Cruz et al., 1995). The caffeine-evoked release of $\mathrm{Ca}^{2+}$ from intracellular stores is typically observed as a transient increase in $\left[\mathrm{Ca}^{2+}\right]_{\mathrm{i}}$. We observed caffeine-evoked transient $\left[\mathrm{Ca}^{2+}\right]_{\mathrm{i}}$ increases in inner segments and synaptic terminals but not in outer segments of rods. Figure $1 A$ illustrates, in the inner segment of a rod, transient increases of $\left[\mathrm{Ca}^{2+}\right]_{\mathrm{i}}$ produced by brief puffs of caffeine $(50 \mathrm{~mm}$ in the pipette). In control saline containing $2 \mathrm{mM} \mathrm{KCl},\left[\mathrm{Ca}^{2+}\right]_{\mathrm{i}}$ was elevated transiently by $\sim 50 \mathrm{nM}$. Caffeine-evoked increases of $\left[\mathrm{Ca}^{2+}\right]_{\mathrm{i}}$ ranged from 20 to $80 \mathrm{~nm}$ under these same conditions ( $n=10$ cells). Responses to repeated puffs of caffeine in calciumfree saline gradually diminished over time but began to increase after a return to control saline (Fig. $1 A$ ). These findings are not only indicative of a caffeine-sensitive store in the rods but demonstrate that the stores can be depleted if calcium influx from the extracellular milieu is diminished. The major influx pathway for calcium influx into rods is via L-type calcium channels (Corey et al., 1984; Krizaj and Copenhagen, 1998). In agreement with a requirement for influx through these channels to fill the caffeinesensitive stores, we found that repeated caffeine puffs in nifedipine, an L-type channel antagonist, caused the transient $\left[\mathrm{Ca}^{2+}\right]_{\mathrm{i}}$ elevations to run down (data not shown) similar to the rundown in $0 \mathrm{Ca}^{2+}$ conditions shown in Figure $1 A$.

The magnitude of caffeine-evoked $\left[\mathrm{Ca}^{2+}\right]_{\mathrm{i}}$ transients was positively correlated to the basal calcium concentration in the rods. Figure $1 B$ plots the peak amplitude of the caffeine transient versus prestimulus $\left[\mathrm{Ca}^{2+}\right]_{\mathrm{i}}$. This finding agrees with previous studies indicating that the releasable pool of calcium from stores is enhanced in proportion to the amount of calcium in the cytosol (Sitsapesan and Williams, 1990; Hua et al., 1993; Garaschuk et al., 1997).

\section{Caffeine also evokes a prolonged $\left[\mathrm{Ca}^{2+}\right]_{\mathrm{i}}$ depression in rods}

At membrane potentials equivalent to the resting potential of rods in darkness (approximately $-40 \mathrm{mV}$ ), caffeine evoked a prolonged depression in $\left[\mathrm{Ca}^{2+}\right]_{\mathrm{i}}$ after the initial peak (Fig. $2 A$ ). Basal $\left[\mathrm{Ca}^{2+}\right]_{\mathrm{i}}$ in isolated cells in $2 \mathrm{~mm} \mathrm{KCl}$ was $49 \pm 3 \mathrm{~nm}$ 
A

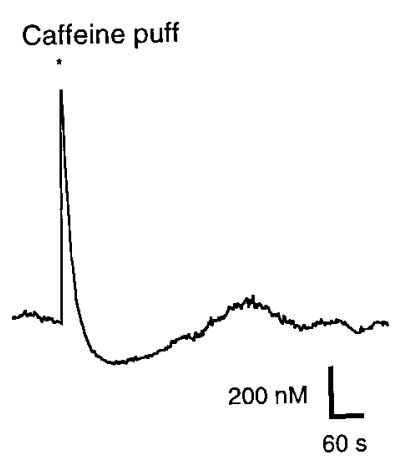

B

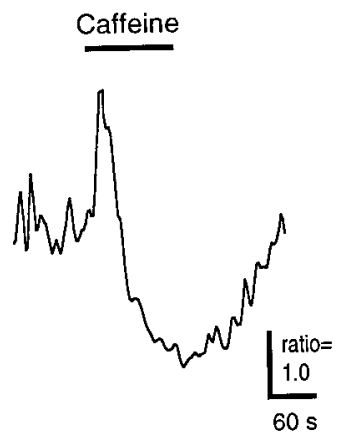

Figure 2. Caffeine also evokes prolonged depression in the inner segments and synaptic terminals of rods when basal $\left[\mathrm{Ca}^{2+}\right]_{\mathrm{i}}$ is higher. $A$, Response in a rod inner segment to a puff of caffeine $(50 \mathrm{~mm}$ in the pipette) in $20 \mathrm{~mm} \mathrm{KCl}$ saline. $\left[\mathrm{Ca}^{2+}\right]_{\mathrm{i}}$ started at $\sim 480 \mathrm{~nm}$, peaked at $\sim 1450 \mathrm{nM}$, and dropped to $\sim 250 \mathrm{nM}$. $\left[\mathrm{Ca}^{2+}\right]_{\mathrm{i}}$ recovered to the prestimulus level $\sim 5 \mathrm{~min}$ after the puff. $B$, Response to caffeine measured in the synaptic terminal of a rod. Calibration with ionomycin was not completed in this cell; therefore only the relative ratio of $340 / 380 \mathrm{~nm}$ fluorescence, known to be directly proportional to $\left[\mathrm{Ca}^{2+}\right]_{\mathrm{i}}$, is shown.

(mean $\pm \mathrm{SE} ; n=70$ ). We found that $20 \mathrm{~mm} \mathrm{KCl}$ raised the membrane potential from approximately $-55 \mathrm{mV}$ to approximately $-40 \mathrm{mV}$ and elevated the resting $\left[\mathrm{Ca}^{2+}\right]_{\mathrm{i}}$ to $325 \pm 16 \mathrm{nM}$ $(n=54)$. At $20 \mathrm{~mm} \mathrm{KCl}$ caffeine elicited a stereotyped two-phase response in $\left[\mathrm{Ca}^{2+}\right]_{\mathrm{i}}$. The first phase was a transient increase in $\left[\mathrm{Ca}^{2+}\right]_{\text {i }}$ peaking at $\sim 5-30 \mathrm{sec}$, whereas the second phase was a prolonged $\left[\mathrm{Ca}^{2+}\right]_{\mathrm{i}}$ undershoot. Figure $2 A$ shows an example from an inner segment of a rod in which caffeine was applied in the presence of $20 \mathrm{~mm} \mathrm{KCl}$. Here $\left[\mathrm{Ca}^{2+}\right]_{\mathrm{i}}$ rose transiently from $\sim 480$ to $\sim 1450 \mathrm{~nm}$ and then rapidly dropped to a level around $250 \mathrm{nM}$, well below the precaffeine level. Figure $2 B$ shows an example of a caffeine-evoked increase and subsequent depression in a synaptic terminal of a rod. These results demonstrate that for rods maintained near their dark resting potential in these cells, caffeine evoked a transient rise, followed by a prolonged depression of $\left[\mathrm{Ca}^{2+}\right]_{\mathrm{i}}$ in inner segments and synaptic terminals. Caffeine did not evoke a transient peak or depression in rod outer segments.

Higher basal levels of $\left[\mathrm{Ca}^{2+}\right]_{\mathrm{i}}$ not only increased the size of the transient peak but increased the speed of the falling phase after the peak and the magnitude of the depression. Figure $3 A-C$ shows a caffeine response recorded from the same rod at $\left[\mathrm{Ca}^{2+}\right]_{i}$ of $\sim 50, \sim 350$, and $\sim 530 \mathrm{~nm}$, respectively. The magnitudes of the transient peaks and the size of the depression were larger at higher basal $\left[\mathrm{Ca}^{2+}\right]_{\mathrm{i}}$. Notably, the fall of calcium after the peak was significantly faster for higher basal $\left[\mathrm{Ca}^{2+}\right]_{\mathrm{i}}$. Singleexponential fits to the falling phase revealed time constants of 97 sec in $2 \mathrm{~mm} \mathrm{KCl}$ and 42 and $40 \mathrm{sec}$, respectively, in 30 and $90 \mathrm{~mm}$ $\mathrm{KCl}$. The depression below the prestimulus levels and the faster decline at raised $\left[\mathrm{Ca}^{2+}\right]_{i}$ suggest the activation of a second process, subsequent to the transient peak, that actively lowers calcium in the cytosol.

In some types of cell, ryanodine can block caffeine-induced release of $\mathrm{Ca}^{2+}$ from intracellular stores (McPherson et al., 1991). However, there is also precedent for caffeine releasing calcium from ryanodine-insensitive stores (Schmid et al., 1990; McNulty and Taylor, 1993; Orkand and Thomas, 1995). We tested the effects of ryanodine on the caffeine-induced rise and depression of $\left[\mathrm{Ca}^{2+}\right]_{\mathrm{i}}$ and found that, by itself, ryanodine slightly raised baseline $\left[\mathrm{Ca}^{2+}\right]_{i}$ in 7 of 21 rods. It also irreversibly eliminated caffeine-mediated elevations of $\left[\mathrm{Ca}^{2+}\right]_{\mathrm{i}}$ in the great majority of
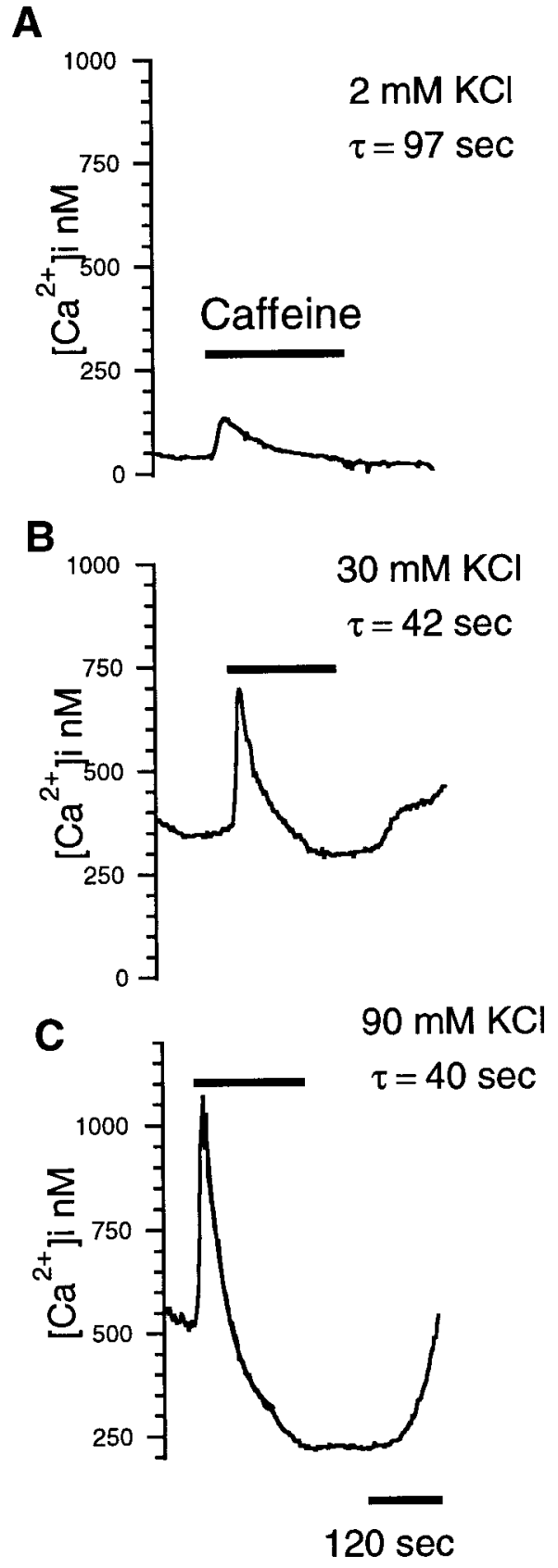

Figure 3. Caffeine-induced depression is higher for increased basal calcium. $A-C,\left[\mathrm{Ca}^{2+}\right]_{\mathrm{i}}$ responses of a rod inner segment to bath-applied caffeine in $2 \mathrm{mM}(A), 30 \mathrm{~mm}(B)$, and $90 \mathrm{~mm}(C) \mathrm{KCl}$. The magnitudes of the transient peak and depression were positively correlated to basal $\left[\mathrm{Ca}^{2+}\right]_{\mathrm{i}}$ before caffeine. The decay from the initial peaks was fitted with single-exponential functions having time constants of 97,42 , and $40 \mathrm{sec}$.

cells $(n=19 / 21)$. Ryanodine, however, only reduced and did not completely eliminate the caffeine-induced suppression of $\left[\mathrm{Ca}^{2+}\right]_{\mathrm{i}}$. In the control experiments caffeine suppressed $\left[\mathrm{Ca}^{2+}\right]_{\mathrm{i}}$ by $75 \pm 5 \%$ of prestimulus levels. After exposure to $20-100 \mu \mathrm{M}$ ryanodine, $\left[\mathrm{Ca}^{2+}\right]_{\mathrm{i}}$ was reduced to $51 \pm 4 \%$ of baseline $(n=12$ rods). In Figure 4, the left trace shows the response to caffeine in control saline. The middle and right traces show the caffeine response 12 and $30 \mathrm{~min}$ after ryanodine application, respectively. This differential effect of ryanodine on the two phases suggests that the transient elevation may be from a predominantly 


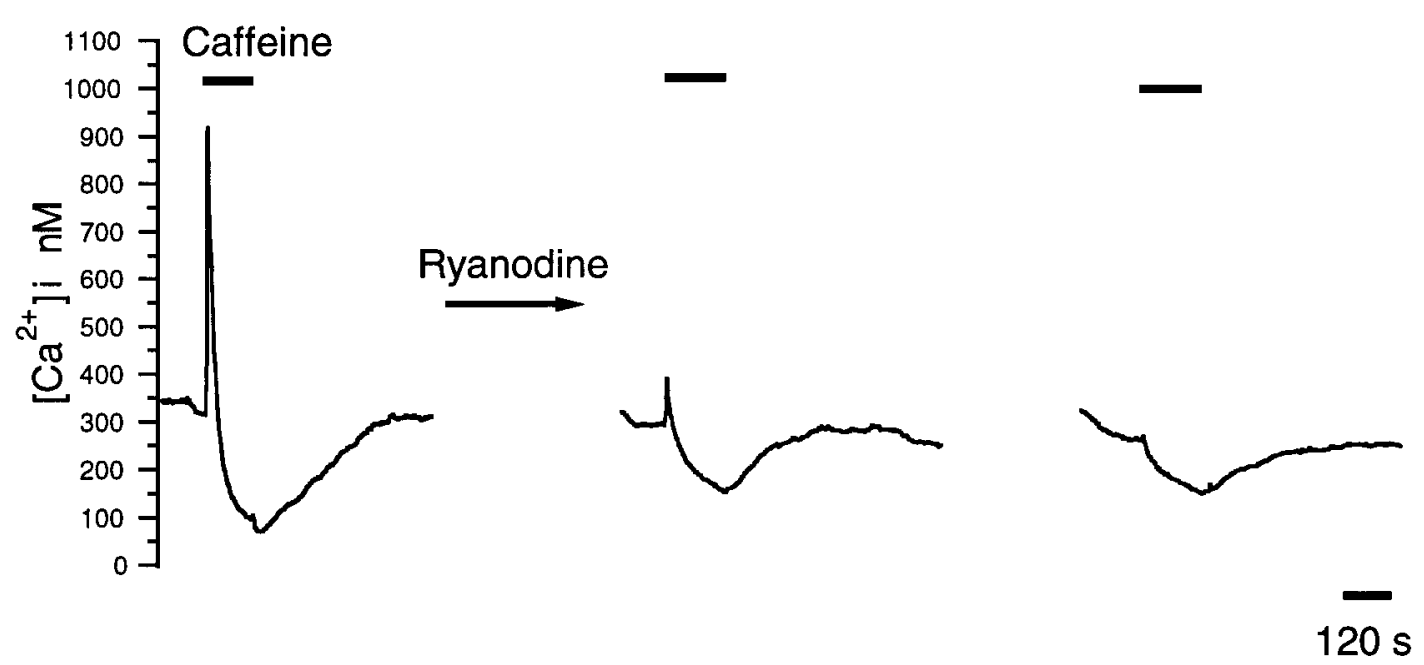

Figure 4. Ryanodine completely blocks caffeine-induced transient peaks in $\left[\mathrm{Ca}^{2+}\right]_{\mathrm{i}}$ but only partially blocks the caffeine-induced depression of $\left[\mathrm{Ca}{ }^{2+}\right]_{\mathrm{i}}$. Left, Caffeine $(10 \mathrm{mM})$ elicited the two-phased $\left[\mathrm{Ca}^{2+}\right]_{\mathrm{i}}$ response in a rod constantly depolarized with $20 \mathrm{~mm} \mathrm{KCl}$. Middle, Right, Caffeine was reapplied at $t=12$ and $30 \mathrm{~min}$ after exposure to $50 \mu \mathrm{M}$ ryanodine. After ryanodine, the first phase of the caffeine-mediated response was irreversibly blocked, and the $\left[\mathrm{Ca}^{2+}\right]_{\mathrm{i}}$ undershoot was reduced to 56 and $44 \%$ of control at $t=12$ and $30 \mathrm{~min}$, respectively.

A

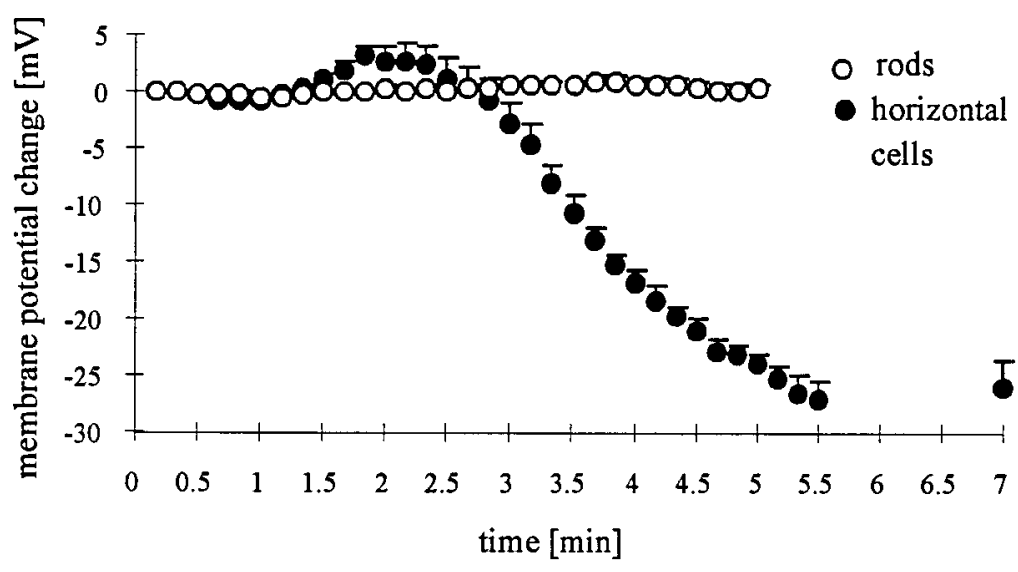

B

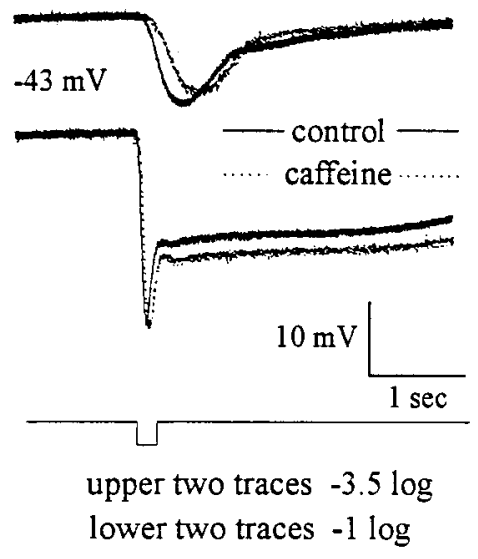

Figure 5. Caffeine hyperpolarizes horizontal cells but not rods. Intracellular recordings from rods and HCs in the eyecup preparation are shown. $A$, Caffeine $(10 \mathrm{mM}$ ) was added at $t=0 \mathrm{~min}$. No effect on the membrane potential of rods was discerned (open circles), whereas horizontal cells ( filled circles) had a two-phased response - transient depolarization followed by a peak hyperpolarization of $26 \pm 2.5 \mathrm{mV}(n=7)$. The effects of caffeine were reversible. In five of six cells recorded for $>20 \mathrm{~min}$ after caffeine washout, the membrane potential returned to within $3 \mathrm{mV}$ of prestimulus values. $B$, Light responses of a rod to $200 \mathrm{msec}, 567 \mathrm{~nm}$ flash (top, $-3.5 \mathrm{log}$; bottom, $-1.0 \log$ quanta) before and during caffeine exposure are shown. In caffeine, slightly slower rise times were observed for dim but not for stronger flashes. No significant effect of caffeine was observed on either the transient hyperpolarization of the rod or the rod "tail" for brighter flashes. Plotted membrane potentials were normalized to the resting potential before caffeine.

ryanodine-sensitive store but the depressive action might involve caffeine effects on both ryanodine-sensitive and -insensitive stores. Accordingly, the depression may result from the activation of a pump or transporter that is triggered by the release of calcium from both types of stores (Schmid et al., 1990; Friel and Tsien, 1992; McNulty and Taylor, 1993; Orkand and Thomas, 1995).

In the following experiments we studied the effects of caffeine on synaptic transmission from rods to second-order cells.

\section{Caffeine hyperpolarizes horizontal cells but not rods}

In dark-adapted amphibian retinas, the membrane potentials of $\mathrm{HCs}$ in darkness reflect the activation of non-NMDA glutamate receptors by the tonic release of glutamate from photoreceptors (Krizaj et al., 1994). We tested the effects of caffeine on synaptic transmission by recording from HCs and rods in dark-adapted eyecup preparations of both Xenopus and tiger salamander retinas. The waveform and the chromatic sensitivity of HC lightevoked responses indicated that the HCs were driven solely by rods. The membrane potentials of rods in darkness were monitored during exposure to $10 \mathrm{~mm}$ caffeine. The initial dark membrane potentials varied from -39 to $-45 \mathrm{mV}$, and they were essentially unchanged throughout the exposure to caffeinecontaining saline (Fig. $5 A$, open circles). Figure $5 B$ shows that the light-evoked responses of rods were altered little by exposure to 10 mM caffeine $(n=6)$. In HCs, caffeine elicited a brief period of depolarization followed by a more prolonged period of hyperpolarization. The resting potentials of $\mathrm{HCs}$ were $-43 \pm 4 \mathrm{mV}$. Figure $5 A$ (filled circles) shows that the HC membrane began to 


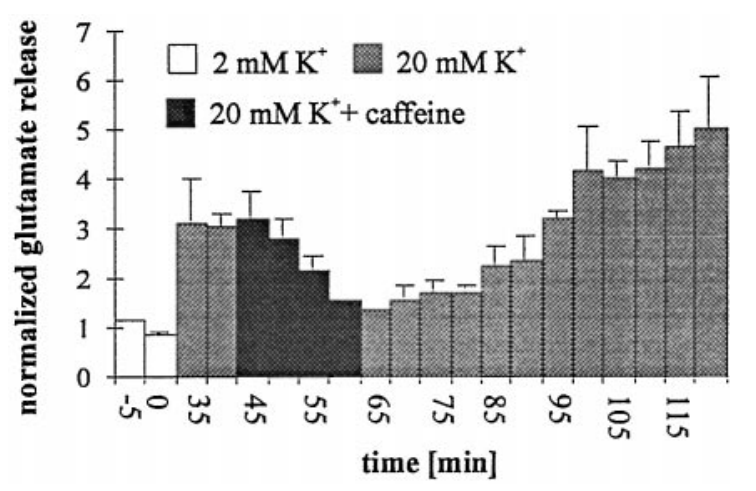

Figure 6. Glutamate release is reduced during exposure to $10 \mathrm{~mm}$ caffeine. The time course of glutamate release from the retina prepared as a photoreceptor sheet is shown. These reduced preparations were depolarized with $20 \mathrm{~mm} \mathrm{KCl} \mathrm{(gray} \mathrm{bars)} \mathrm{at} t=0 \mathrm{~min}$ after stabilization in 2 $\mathrm{mm} \mathrm{KCl} \mathrm{(white} \mathrm{bars).} \mathrm{In} \mathrm{these} \mathrm{experiments,} \mathrm{glutamate} \mathrm{release} \mathrm{stabilized}$ after $35 \mathrm{~min}$ in $20 \mathrm{~mm} \mathrm{KCl}$, which is when the first measurements were made. Glutamate release was markedly suppressed by caffeine added at $t=45 \mathrm{~min}$ (to $47 \%$ of control; black bars). Each bar represents the glutamate content of 5 min samples of the perfusate. The effect of caffeine was reversible; during the washout (at $t=65 \mathrm{~min}$ ) a consistent rebound increase in glutamate release was observed $(n=15)$.

depolarize within 2 min after the switch to caffeine-containing saline. After reaching a mean peak depolarization of $4 \mathrm{mV}$, the HCs hyperpolarized by $26 \pm 2.5 \mathrm{mV}$ over the next $4-5 \mathrm{~min}$. The filled circles (Fig. $5 A$ ) show the mean and SE of seven HCs. These data indicate that caffeine has little effect on the rod membrane potential in darkness but strongly modulates the membrane potential of HCs. Given that the depolarization and subsequent hyperpolarization of $\mathrm{HCs}$ have a time course similar to the caffeine-induced rise and depression of $\left[\mathrm{Ca}^{2+}\right]_{\mathrm{i}}$ measured in the rods, we hypothesize that caffeine-evoked changes of calcium in the presynaptic neurons modulates the release of neurotransmitter from these cells. Because the membrane potentials of rods are not affected, the data tend to rule out a caffeine-dependent, voltage-induced suppression of transmitter release in rods.

\section{Caffeine inhibits glutamate release}

We tested directly whether caffeine could modulate endogenous glutamate release from photoreceptors. These experiments were performed using a photoreceptor sheet preparation (Schmitz and Witkovsky, 1996). We approximated the same conditions used for isolated rods (Fig. 2) by suppressing the dark current with light and then adding $20 \mathrm{~mm}\left[\mathrm{~K}^{+}\right]_{0}$ to increase glutamate release. Figure 6 shows that 35 min after a switch from normal to $20 \mathrm{mM}$ $\mathrm{KCl}$ saline, glutamate release increased $3.12 \pm 0.35$ times $(n=4)$. After addition of $10 \mathrm{~mm}$ caffeine to the $20 \mathrm{~mm} \mathrm{~K}^{+}$-containing saline, glutamate release declined to $47 \%$ of baseline levels over a 15-20 min period. The decline was statistically significant $(p<$ $0.001)$. After return to control saline without caffeine, recovery was complete after $\sim 40-45 \mathrm{~min}$. These data indicate that the effect of caffeine on synaptic transmission between rods and horizontal cells is consistent with a presynaptic locus of caffeine action, in which caffeine directly or indirectly suppresses exocytosis from the rods.

The concentration dependence of caffeine is shown in Figure $7 A$. Superfusion with $1 \mathrm{~mm}$ caffeine had no effect on glutamate release. On the other hand, exposure to either 5 or $10 \mathrm{~mm}$ caffeine resulted in very similar reductions in glutamate release. The concentration dependence of caffeine on glutamate release

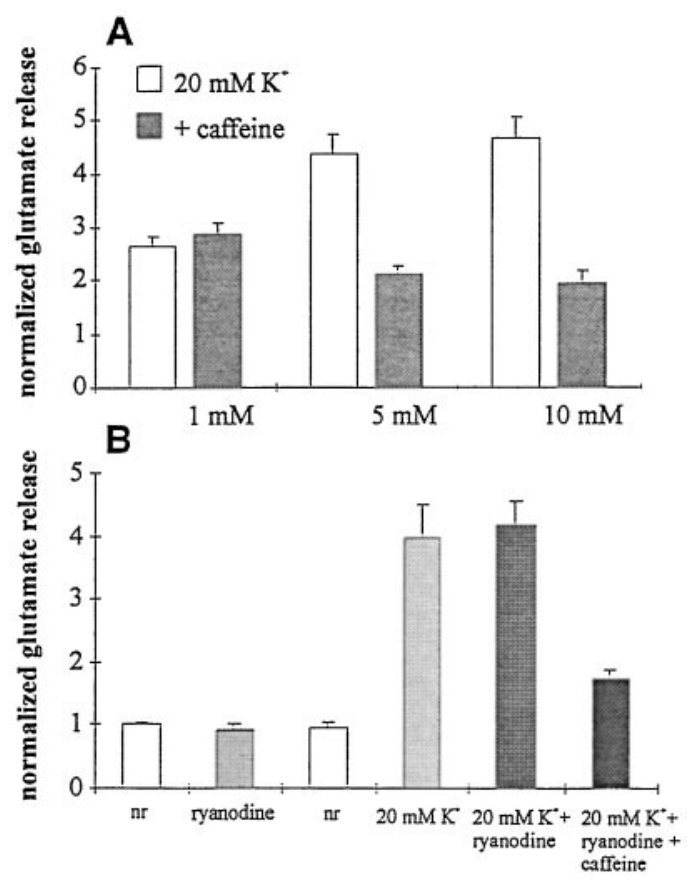

Figure 7. Dose dependence and ryanodine sensitivity of the caffeineevoked reduction in glutamate release. $A$, The effect of caffeine (filled bars) versus control (open bars) on release was observed at $5 \mathrm{~mm}(2.14 \pm$ 0.14 vs $4.37 \pm 0.35$ control $)$ and $10 \mathrm{mM}(1.96 \pm 0.23$ vs $4.67 \pm 0.41$ control $)$ caffeine but not with $1 \mathrm{~mm}$ caffeine $(2.86 \pm 0.22 \mathrm{vs} 2.64 \pm 0.19$ in control). $B$, Ryanodine $(20 \mu \mathrm{M})$ had no effect on glutamate release from reduced retinas under normal conditions or when depolarized by $\mathrm{KCl}(20 \mathrm{~mm})$. Data are normalized to the average of the control samples (open bars). In the presence of ryanodine, $10 \mathrm{~mm}$ caffeine still suppressed glutamate release by $42.5 \%$.

matches well that on $\left[\mathrm{Ca}^{2+}\right]_{\mathrm{i}}$. Because ryanodine reduced the caffeine-mediated depression of $\left[\mathrm{Ca}^{2+}\right]_{i}$, it might be expected to reduce the action of caffeine on release of glutamate from rods. We found that ryanodine alone at $20 \mu \mathrm{M}$ had no effect on glutamate release, either in normal saline or in the $20 \mathrm{~mm} \mathrm{KCl}$ saline (Fig. 7B). In the presence of ryanodine, moreover, $10 \mathrm{~mm}$ caffeine still produced a $59 \%$ inhibition of glutamate release $(4.17 \pm 0.38$ vs $1.72 \pm 0.17 ; n=8)($ Fig. $7 B)$. Although ryanodine blocked approximately one-third of caffeine-evoked $\left[\mathrm{Ca}^{2+}\right]_{\mathrm{i}} \mathrm{de}-$ pression, these experiments did not reveal an effect of ryanodine on caffeine-suppressed glutamate release.

\section{Caffeine inhibits calcium current in isolated rods}

The data presented so far suggest that caffeine affects exocytosis by modulating $\mathrm{Ca}^{2+}$ release from stores, resulting in alterations of $\left[\mathrm{Ca}^{2+}\right]_{\mathrm{i}}$. An alternative, but not mutually exclusive, hypothesis is that caffeine modulates $\mathrm{Ca}^{2+}$ influx through the voltagedependent $\mathrm{Ca}^{2+}$ channels in rods. The following experiments tested that hypothesis. Figure 8 illustrates an $I-V$ curve for an L-type calcium current recorded from a rod in whole-cell mode. This current, $I_{\mathrm{Ca}}$, peaked at $\sim 0 \mathrm{mV}$ (Fig. $8 A$ ) and showed little inactivation during $120 \mathrm{msec}$ voltage steps when the pipette solution contained $10 \mathrm{~mm}$ EGTA (see Fig. 8A, inset). $I_{\mathrm{Ca}}$ was completely blocked by $\mathrm{Cd}^{2+}(100 \mu \mathrm{M} ; n=26$; data not shown). Caffeine $\left(5\right.$ and $10 \mathrm{~mm}$ ) reversibly suppressed peak $I_{\mathrm{Ca}}$ by $35.4 \pm$ 3.1 and $50.0 \pm 2.7 \%$, respectively $(n=29$; Fig. $8 A, B)$. Caffeine had no detectable effect on the voltage range over which $I_{\mathrm{Ca}}$ was activated. Often during caffeine washout, a rebound increase in $\mathrm{Ca}^{2+}$ currents was observed (Fig. $8 B$, arrow), with the $\mathrm{Ca}^{2+}$ 

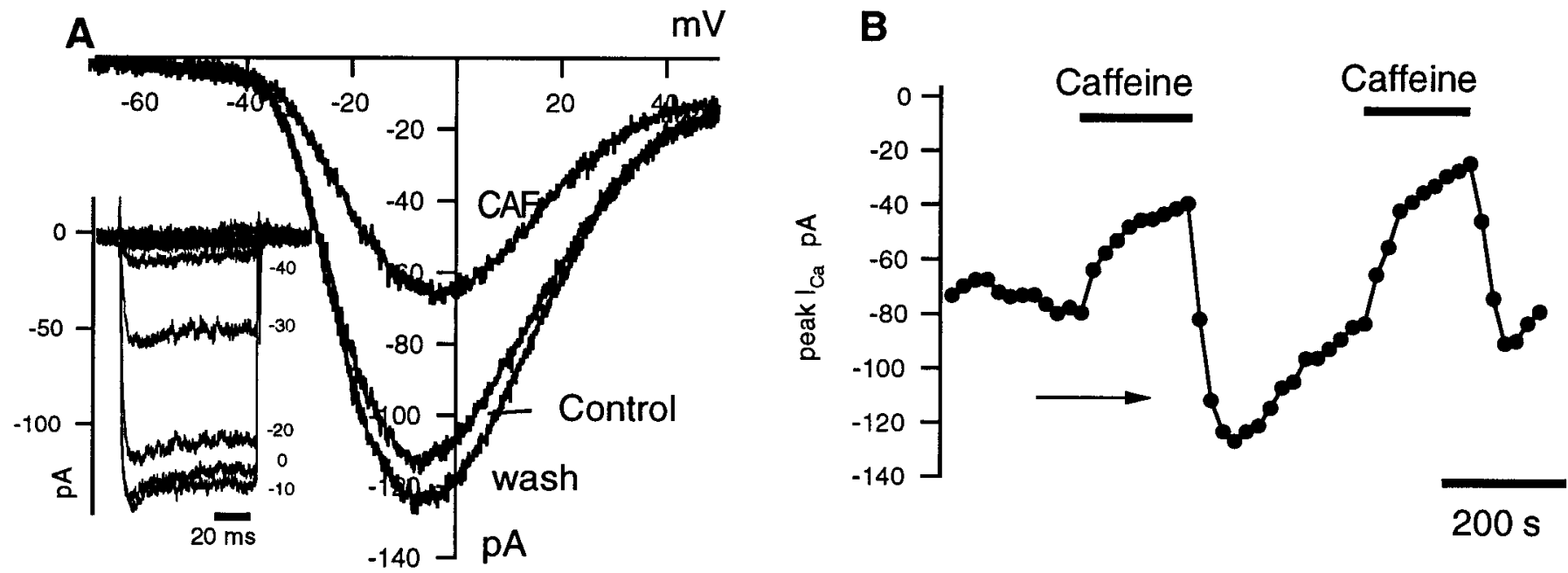

Figure 8. Caffeine reduces $I_{\mathrm{Ca}}$ in rods. Calcium current was recorded with whole-cell patch pipettes. $A$, Calcium currents were evoked with voltage-clamp ramps from -70 to $+50 \mathrm{mV}$ and with voltage-clamp steps (inset, -70 to $+50 \mathrm{mV}$ in $10 \mathrm{mV}$ increments). Caffeine (CAF; $10 \mathrm{~mm})$ reduced the peak amplitude (at $-10 \mathrm{mV}$ ) but did not affect the activation voltage. Note the rebound increase in $I_{\mathrm{Ca}}$ after washout of caffeine. $B$, Time course of caffeine action on $I_{\mathrm{Ca}}$ is shown. The cell was held at $-70 \mathrm{mV}$ and stepped for $120 \mathrm{msec}$ to $0 \mathrm{mV}$. Test pulses were applied every 20 sec. Sequential application of $10 \mathrm{~mm}$ caffeine reversibly reduced $I_{\mathrm{Ca}}$. After the first washout, $I_{\mathrm{Ca}}$ rebounded to levels above control.

current returning to its precaffeine level after a $4-6$ min wash (Fig. $8 A, B$ ).

\section{The predominant action of caffeine on $I_{\mathrm{Ca}}$ in rods requires changes in $\left[\mathrm{Ca}^{2+}\right]_{\mathrm{i}}$}

The suppression of $I_{\mathrm{Ca}}$ by caffeine could result from either a direct caffeine action on the $\mathrm{Ca}^{2+}$ channel or an indirect one mediated by release of $\mathrm{Ca}^{2+}$ from intracellular stores (Pacaud et al., 1987; Kramer et al., 1994; Adachi-Akahane et al., 1996) or both. The indirect action of caffeine should be reduced or eliminated by blockers of $\mathrm{Ca}^{2+}$ release from stores. Figure $9 A$ shows that in the presence of ryanodine the inhibitory action of $10 \mathrm{~mm}$ caffeine on peak $I_{\mathrm{Ca}}$ was reduced by approximately one-half. In ryanodine the mean reduction of peak current was $25.7 \pm 5.8 \%$ $(n=8)$ versus $50.0 \pm 2.7 \%$ in control. These data indicate that more than one-half of the caffeine-induced suppression of $I_{\mathrm{Ca}}$ results from release from ryanodine-sensitive stores.

The inhibitory effect of caffeine on $I_{\mathrm{Ca}}$ was much more pronounced in the presence of intrapipette EGTA compared with BAPTA, a $\mathrm{Ca}^{2+}$ chelator with a higher affinity for $\mathrm{Ca}^{2+}$ and faster kinetics of binding (Tsien, 1980). In the rod shown in Figure $9 B$, intracellular BAPTA blocked virtually all the caffeine-induced suppression of $I_{\mathrm{Ca}}$. In summary, we found that when rods were loaded with 10-20 mM BAPTA, the average peak amplitude of $I_{\mathrm{Ca}}$ was significantly larger than that in controls $(186.6 \pm 74.5 \mathrm{pA} ; n=5)$. This larger current is consistent with the idea that $I_{\mathrm{Ca}}$ is being tonically inhibited by cytosolic calcium. In these BAPTA-loaded cells, the inhibitory effect of caffeine on $\mathrm{Ca}^{2+}$ current was substantially reduced. Caffeine reduced $I_{\mathrm{Ca}}$ by $20.3 \pm 7.7 \%$. The difference between control and caffeine's action was not significant statistically. These experiments demonstrate that a major proportion of caffeine's suppression of $I_{\mathrm{Ca}}$ can be attributed to effects of caffeine on intracellular calcium.

Further indication that $\mathrm{Ca}^{2+}$ released by caffeine acts to inhibit $I_{\mathrm{Ca}}$ was provided by experiments in which $\left[\mathrm{Ca}^{2+}\right]_{\mathrm{o}}$ was replaced by $10 \mathrm{~mm}\left[\mathrm{Ba}^{2+}\right]_{\mathrm{o}}$. Although $\mathrm{Ba}^{2+}$ currents are well supported by neuronal L-type calcium channels, including those of photoreceptors (Corey et al., 1984; Tsien et al., 1988), several features of cellular $\mathrm{Ba}^{2+}$ regulation differ from the regulation of $\mathrm{Ca}^{2+}$. $\mathrm{Ba}^{2+}$, for example, is not recognized by SERCAs and is thus not sequestered into intracellular stores (Schilling et al., 1989; Kwan and Putney, 1990). Moreover, in contrast to $\mathrm{Ca}^{2+}$, cytoplasmic $\mathrm{Ba}^{2+}$ ions do not inactivate calcium channels (Haack and Rosenberg, 1994) and may inhibit release of $\mathrm{Ca}^{2+}$ through ryanodine receptor-gated channels, thus allowing one to differentiate between direct caffeine effects on the conductance or open probability of the L-type calcium channel and its indirect effects on the channel via $\mathrm{Ca}^{2+}$ released from intracellular stores. In rod photoreceptors, peak $I_{\mathrm{Ca}}$ elicited by a depolarizing voltage ramp was $98.7 \pm 13.1 \mathrm{pA}$. After a switch of the superfusate from $\left[\mathrm{Ca}^{2+}\right]_{\mathrm{o}}$ to $\left[\mathrm{Ba}^{2+}\right]_{\mathrm{o}}$, peak $I_{\mathrm{Ca}}$ increased to $300.8 \pm 39.8 \mathrm{pA}$. Caffeine inhibited the $\mathrm{Ba}^{2+}$ current by $27.6 \pm 6.6 \%(n=8$; data not shown) compared with $50 \pm 2.7 \%$ in the $\mathrm{Ca}^{2+}$-containing saline. This result suggests that the upper bound for caffeine-mediated inhibition of $I_{\mathrm{Ca}}$ by direct block of the channels is $55 \%$. In these experiments, if there were residual calcium in the stores after the change to $\mathrm{Ba}^{2+}$, this calcium could have been released by caffeine to inhibit the channels via the indirect pathway (Przywara et al., 1993), resulting in an overestimate of caffeine's direct effect on the channels.

As an alternative method to test whether calcium influx via $I_{\mathrm{Ca}}$ was suppressed in caffeine, we measured $\left[\mathrm{Ca}^{2+}\right]_{\mathrm{i}}$ with fura-2 while recording under voltage clamp with perforated-patch recording pipettes. We found that a depolarization-induced influx of $\mathrm{Ca}^{2+}$ was evident in the presence of caffeine. Figure $9 C$ illustrates that $\left[\mathrm{Ca}^{2+}\right]_{\mathrm{i}}$ decreased when the membrane potential was lowered from -30 to $-65 \mathrm{mV}$, a reflection of deactivation of $I_{\mathrm{Ca}}$. After the caffeine-evoked transient increase in $\left[\mathrm{Ca}^{2+}\right]_{\mathrm{i}}$, the membrane potential was switched back to $-30 \mathrm{mV}$. $\left[\mathrm{Ca}^{2+}\right]_{\mathrm{i}}$ rose to a slightly higher level than the precaffeine level at $-30 \mathrm{mV}$. These data illustrate that depolarization-induced calcium influx is not suppressed by caffeine, indicating that caffeine did not significantly block the L-type channels directly. These data, taken as a whole, indicate that a large proportion of caffeine's effect is a result of caffeine acting inside the rods, presumably by releasing 


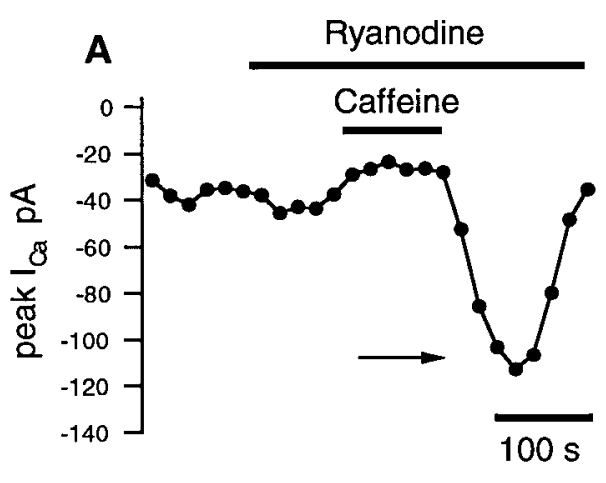

B
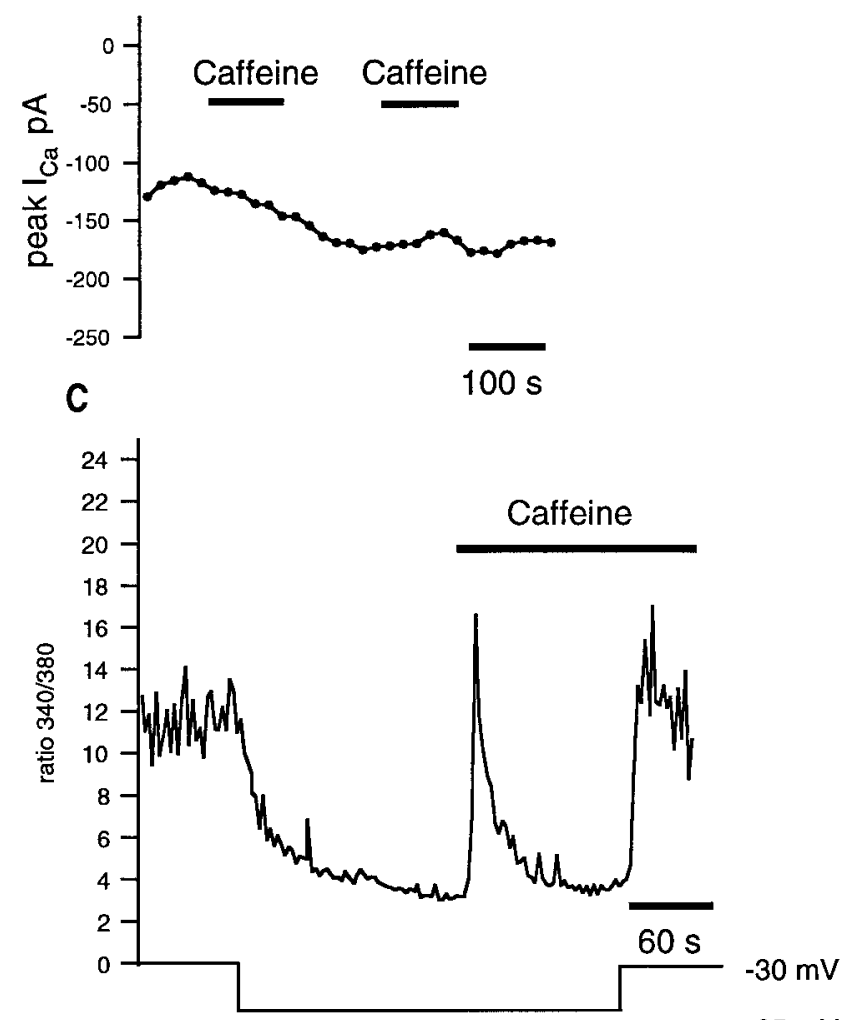

$-65 m V$

Figure 9. Ryanodine and BAPTA reduce the effectiveness of caffeine on $I_{\mathrm{Ca}}$. The rods were held at $-70 \mathrm{mV}$ and periodically $(0.02 \mathrm{~Hz})$ depolarized with a voltage ramp to $+50 \mathrm{mV}$. The peak of $I_{\mathrm{Ca}}$ is plotted in $A$ and $B$. $A$, Ryanodine $(20 \mu \mathrm{M})$ suppressed the caffeine-mediated decrease in $I_{\mathrm{Ca}} . B$, This rod was dialyzed with $10 \mathrm{~mm}$ BAPTA in the patch pipette. Repetitive applications of caffeine did not reduce peak $I_{\mathrm{Ca}}$ under these conditions. $C,\left[\mathrm{Ca}^{2+}\right]_{\mathrm{i}}$ was monitored in a rod held under voltage clamp with a perforated patch electrode. The switch in potential from -30 to $-65 \mathrm{mV}$ reduced $\left[\mathrm{Ca}^{2+}\right]_{\mathrm{i}}$. Caffeine evoked a transient increase in $\left[\mathrm{Ca}^{2+}\right]_{\mathrm{i}}$. Switching the membrane potential back to $-30 \mathrm{mV}$ increased $\left[\mathrm{Ca}^{2+}\right]_{i}$, indicating that the voltage-dependent channels were not closed by caffeine.

calcium from stores. Experiments discussed below add support to the idea that it is calcium release from stores that suppresses $\left[\mathrm{Ca}^{2+}\right]_{\mathrm{i}}$.

\section{Chlorocresol, a nonxanthine store-releasing compound, and spontaneous calcium spikes produce a depression in $\left[\mathrm{Ca}^{2+}\right]_{\mathrm{i}}$}

Xanthines, such as caffeine, inhibit phosphodiesterases (PDEs) in addition to releasing calcium from stores (Nehlig et al., 1992). To test whether the caffeine-induced changes in $\left[\mathrm{Ca}^{2+}\right]_{i}$ were separable from any inhibition of PDEs, we used 4-CmC, a nonxanthine compound that releases calcium from stores (Zorzato et al., 1993; Cseresnyes et al., 1997). Figure 10 shows the action of 4-CmC on $\left[\mathrm{Ca}^{2+}\right]_{\mathrm{i}}$ in a rod. $4-\mathrm{CmC}$ elevated $\left[\mathrm{Ca}^{2+}\right]_{\mathrm{i}}$ transiently and evoked a prolonged decrease, similar to the undershoot elicited by caffeine $(n=13)$. $4-\mathrm{CmC}$ was shown to release $\left[\mathrm{Ca}^{2+}\right]_{\mathrm{i}}$ from the stores at a much slower rate than caffeine (Cseresnyes et al., 1997); hence the transient rise in calcium might be expected to be smaller than that in caffeine. Similar depressions in $\left[\mathrm{Ca}^{2+}\right]_{\mathrm{i}}$ were observed in thymol, another nonxanthine compound known to release $\mathrm{Ca}^{2+}$ from stores $(n=4$; data not shown).

Spikes of $\left[\mathrm{Ca}^{2+}\right]_{\mathrm{i}}$ observed in neuronal and non-neuronal cells primarily result from the spontaneous release of calcium from ryanodine-sensitive stores (Berridge, 1998). We observed that spontaneous spikes in rod $\left[\mathrm{Ca}^{2+}\right]_{i}$ often were followed by a depression of $\left[\mathrm{Ca}^{2+}\right]_{\mathrm{i}}$ below the resting level. Figure $10 \mathrm{~B}$ illustrates caffeine-evoked increases and depression of $\left[\mathrm{Ca}^{2+}\right]_{\mathrm{i}}$ recorded from two rods simultaneously. In between caffeine applications, a spontaneous increase in $\left[\mathrm{Ca}^{2+}\right]_{i}$, termed a calcium spike, occurred in one of the rods but not in the other. The increase (Fig. 10B, thick open arrow) was followed by an undershoot (thin filled arrow). The existence of the depressive phases after a spike suggests that even a noncaffeine-mediated release can cause a depression of $\left[\mathrm{Ca}^{2+}\right]_{\mathrm{i}}$, supporting the hypothesis that it is the transient release of calcium that triggers the prolonged decrease in intracellular calcium concentration.

As a further test of a possible role for caffeine-evoked calcium release in the depression of $\left[\mathrm{Ca}^{2+}\right]_{\mathrm{i}}$, we used fura- 2 to monitor intracellular $\mathrm{Ba}^{2+}$ (Schilling et al., 1989). As mentioned above, because barium is sequestered poorly into stores (Kwan and Putney, 1990; Adachi-Akahane et al., 1996), the effects of caffeine on $\left[\mathrm{Ba}^{2+}\right]_{\mathrm{i}}$ provide a measure of how caffeine affects influx through the calcium channels. Figure 11 shows that replacement of extracellular $\mathrm{Ca}^{2+}$ by $\mathrm{Ba}^{2+}$ increased fura- 2 ratios. This increase reflects the higher permeability of $I_{\mathrm{Ca}}$ to barium. However, $\mathrm{Ba}^{2+}$ substitution for $\mathrm{Ca}^{2+}$ resulted in a block of the caffeine-evoked transient increase and a significant decrease of $\left[\mathrm{Ba}^{2+}+\mathrm{Ca}^{2+}\right]_{\mathrm{i}}$ depression $(16 \pm 4 \%$ relative to the baseline in $2 \mathrm{~mm}\left[\mathrm{Ba}^{2+}\right]_{\mathrm{o}}$ compared with control $82 \pm 3 \%$ relative to the baseline in $\left.2 \mathrm{~mm}\left[\mathrm{Ca}^{2+}\right]_{\mathrm{i}} ; n=6\right)$. This blockage of the initial transient increase is consistent with a diminished release of $\mathrm{Ca}^{2+}$ from the stores. The small degree of caffeine-induced depression in barium indicates that direct effects of caffeine on $I_{\mathrm{Ca}}$ were $<19 \%(=16 / 82)$ of the depression mediated by calcium released from the stores.

\section{DISCUSSION}

We report here that caffeine transiently raises and then depresses $\left[\mathrm{Ca}^{2+}\right]_{\mathrm{i}}$ in rod photoreceptors. Exposure to caffeine also reduces the L-type calcium current. These presynaptic events are paralleled by a transient depolarization and subsequent hyperpolarization of the membrane potential of a second-order retinal neuron, the horizontal cell. Release of endogenous glutamate from rods is also depressed by caffeine. The poor temporal resolution of our glutamate measurements did not allow us to observe a transient increase in release. Our data provide novel evidence that intracellular calcium stores play a role in mediating glutamate release. The main question raised by our findings is the mechanism(s) by which caffeine modulates $\left[\mathrm{Ca}^{2+}\right]_{i}$ and the rate of transmitter release. Figure 12 schematizes the probable mechanisms. These are discussed in detail below. 
A

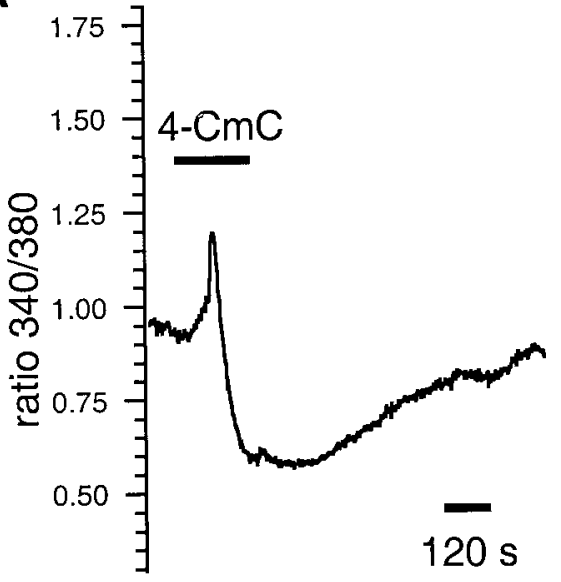

B

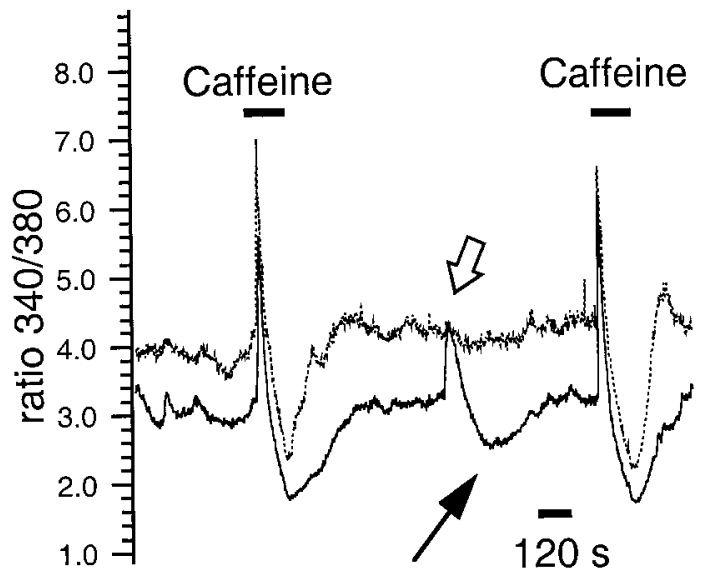

Figure 10. $\left[\mathrm{Ca}^{2+}\right]_{\mathrm{i}}$ is depressed by nonxanthine store-releasing compounds and after spontaneous calcium spikes. $A$, 4-Chloro- $m$-cresol (500 $\left.\mu \mathrm{M}\right)$ evoked a transient peak and a subsequent depression in $\left[\mathrm{Ca}^{2+}\right]_{\mathrm{i}} B$, Ratios $(340 / 380 \mathrm{~nm})$ from two simultaneously recorded rods in 20 mM $\mathrm{KCl}$ are plotted. In this particular recording session, we were not able to perform absolute calibrations of $\left[\mathrm{Ca}^{2+}\right]_{\mathrm{i}}$ on these particular cells and so have used the $340 / 380$ ratio as the indicator of calcium concentration. Caffeine $(10 \mathrm{~mm})$ was applied at 14.9 and $35.4 \mathrm{~min}$. At $t=23.7 \mathrm{~min}$, rod 2 (bottom solid line) exhibited a spontaneous regenerative increase in $\left[\mathrm{Ca}^{2+}\right]_{\mathrm{i}}$ (thick open arrow) followed by an undershoot (thin filled arrow). No such phenomenon was exhibited by rod 1 (top dotted line).

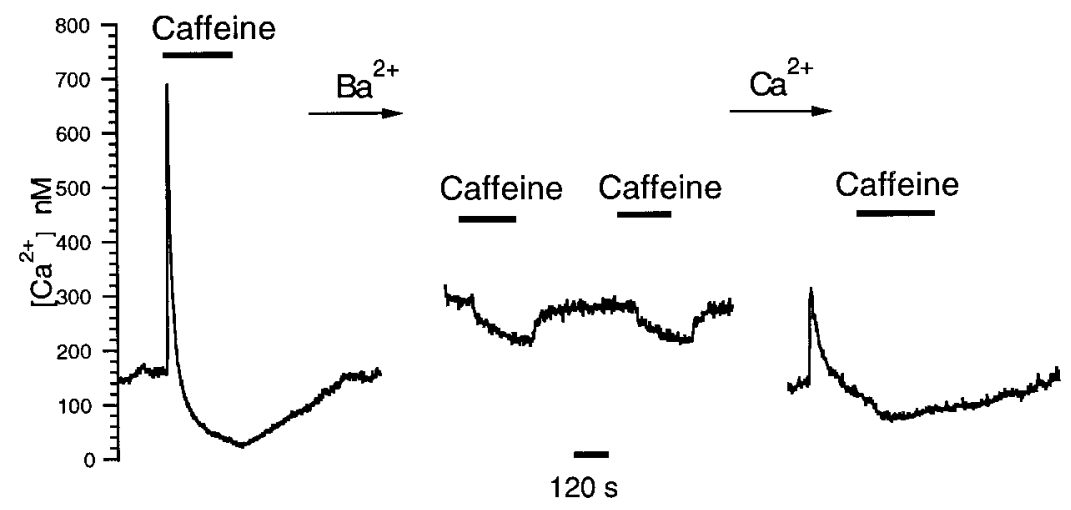

Figure 11. Extracellular barium reduces the effects of caffeine on $\left[\mathrm{Ca}^{2+}\right]$ i. Caffeine was applied before, during, and after barium substitution for extracellular calcium. Left, Caffeine elicited a typical response consisting of a transient increase in $\left[\mathrm{Ca}^{2+}\right]_{\mathrm{i}}$ followed by a depression. Middle, Caffeine evoked a much smaller change in $\left[\mathrm{Ca}^{2+}\right]_{\mathrm{i}}$ (measured here as 340/380 ratios) during $\mathrm{Ba}^{2+}$ substitution. Right, The washout response to caffeine is shown and demonstrates a partial recovery of both the transient elevation and the more prolonged undershoot of $\left[\mathrm{Ca}^{2+}\right]_{\mathrm{i}}$ in $\mathrm{Ca}^{2+}$-containing saline.

\section{Caffeine-evoked transient $\left[\mathrm{Ca}^{2+}\right]_{i}$ increases reflect discharge of calcium from ryanodine-sensitive stores}

The caffeine-mediated transient increase in $\left[\mathrm{Ca}^{2+}\right]_{\mathrm{i}}$ observed in rods has been reported in a multitude of other cell types and reflects immediate calcium release from the stores (Friel and Tsien, 1992; Orkand and Thomas, 1995; Garaschuk et al., 1997). The observation that the magnitude of the transient depended on the basal level of $\left[\mathrm{Ca}^{2+}\right]_{\mathrm{i}}$ (Fig. $1 B$ ) is consistent with greater amounts of calcium being pumped into the caffeine-sensitive stores by the constitutively active SERCA pumps. Supporting evidence of store release comes from our finding that the transient increase in $\left[\mathrm{Ca}^{2+}\right]_{\mathrm{i}}$ is substantially reduced when $\mathrm{Ca}^{2+}$ is replaced with $\mathrm{Ba}^{2+}$ (Fig. 11), a divalent cation that is poorly pumped into stores (Kwan and Putney, 1990). In addition, ryanodine blocked the transient increases of $\left[\mathrm{Ca}^{2+}\right]_{\mathrm{i}}$, suggesting that caffeine acts on an intracellular store expressing a conventional class of ryanodine receptors (Pozzan et al., 1994; Berridge, 1998). It is noteworthy that ryanodine receptors have been reported recently in photoreceptor synaptic terminals (Gabriel et al., 1998). Caffeine-sensitive stores in rods may coexist with the other major class of calcium stores, gated by the inositol trisphosphate receptor (Peng et al., 1991) (Krizaj and Copenhagen, unpublished observations). $\mathrm{Ca}^{2+}$ release from these stores is inhibited by caffeine (Ehrlich et al., 1994) and thus is unlikely to contribute to caffeine-mediated changes in $\operatorname{rod}\left[\mathrm{Ca}^{2+}\right]_{i}$.

Caffeine-evoked calcium release contributes significantly to the reduction of $I_{\mathrm{Ca}}$ and the depression of $\left[\mathrm{Ca}^{2+}\right]_{i}$

We show that caffeine-induced calcium release suppresses $I_{\mathrm{Ca}}$ and depresses $\left[\mathrm{Ca}^{2+}\right]_{\mathrm{i}}$. We propose that a portion of the depression of $\left[\mathrm{Ca}^{2+}\right]_{\mathrm{i}}$ can be attributed to the reduction of calcium entry via $I_{\mathrm{Ca}}$; however there must be additional mechanisms by which $\left[\mathrm{Ca}^{2+}\right]_{\mathrm{i}}$ is depressed. First we will discuss the suppression of $I_{\mathrm{Ca}}$ by caffeine. Intracellular BAPTA, ryanodine, and the substitution of calcium by barium significantly reduced the suppressive action of caffeine on $I_{\mathrm{Ca}}$ (Fig. 9). These experiments can be taken as strong evidence that an intracellular calcium-dependent mechanism, triggered by caffeine, leads to suppression of $I_{\mathrm{Ca}}$. A smaller component of caffeine's action on $I_{\mathrm{Ca}}$ could be attributed to a direct effect in the channels (Hughes et al., 1990). Mechanistically, $I_{\mathrm{Ca}}$ could be inactivated by a localized and restricted rise in caffeine-released calcium near the channel (Adachi-Akahane et al., 1996; Sham, 1997) or by a release-triggered activation of a second messenger cascade. In consideration of the first mechanism, L-type voltage-gated calcium channels are inhibited by 


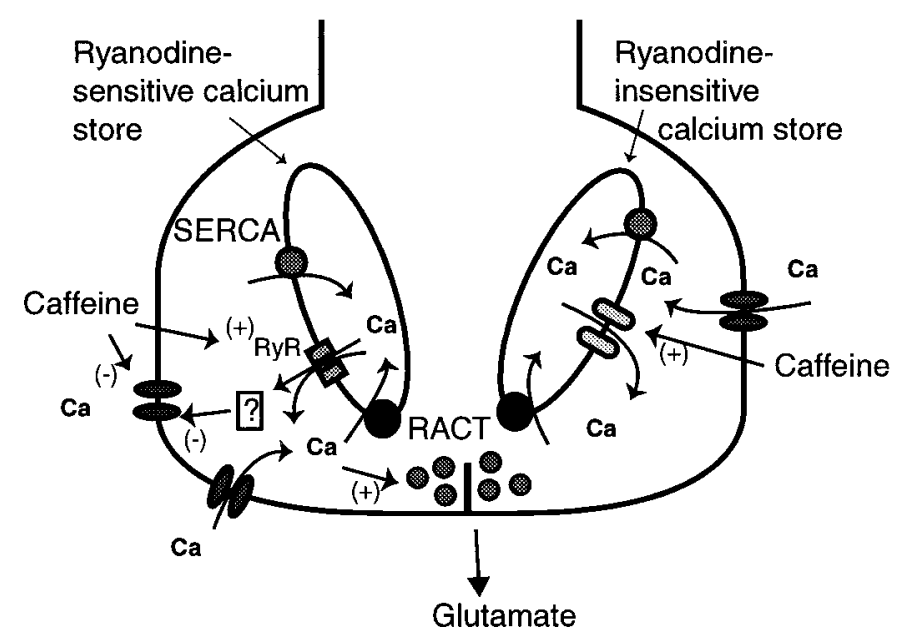

Figure 12. Schematic diagram of the proposed action of caffeine on $I_{\mathrm{Ca}}$ and intracellular stores and the action of store-released calcium on glutamate release, $I_{\mathrm{Ca}}$, and the release-activated calcium transport. Caffeine was shown to suppress $I_{\mathrm{Ca}}$ moderately via a direct action and more significantly via an indirect one in which intracellular calcium led to a decrease in $I_{\mathrm{Ca}}$. Caffeine also caused a transient peak in calcium that is attributable to a caffeine-induced release from stores. The depression of $\left[\mathrm{Ca}^{2+}\right]_{\mathrm{i}}$ can be explained by a release-activated uptake into stores and the suppression of $I_{\mathrm{Ca}}$.

direct binding of $\mathrm{Ca}^{2+}$ to the $\alpha 1$ subunit of the channel (de Leon et al., 1995). Calcium release from both caffeine-sensitive and $\mathrm{IP}_{3}$-gated stores inactivate $\mathrm{Ca}^{2+}$ channels in other cell types (Kramer et al., 1994; Adachi-Akahane et al., 1996; Lara et al., 1997). Consistent with the required proximity of the release site to the calcium channel is our finding that BAPTA, but not EGTA, reduced the caffeine-evoked suppression of $I_{\mathrm{Ca}}$. Similar close proximities were demonstrated in other excitable cell types (Henkart et al., 1976; Walton et al., 1991; Sham, 1997; Tse et al., 1997) including hair cells (Sridhar et al., 1996) and invertebrate photoreceptors (Minke and Selinger, 1996). Alternatively, caffeine-released calcium might activate a second messenger, such as calcineurin (Schumann et al., 1997), or a calcium dependent kinase/phosphatase cascade that regulates the channel directly. If store-released calcium activated a second messenger cascade, the source of calcium need not be as close to the channel.

To depress $\left[\mathrm{Ca}^{2+}\right]_{\mathrm{i}}$, caffeine must either reduce ongoing influx, via an action on $I_{\mathrm{Ca}}$, or stimulate extrusion from the rods or uptake into the stores. An examination of the time course and pharmacology of caffeine-mediated depression indicates that simple suppression of ongoing influx is an insufficient explanation for caffeine's action. As evidence we found that (1) during $250 \mathrm{msec}$ puffs of caffeine, the caffeine-induced depression lasted much longer $(>120 \mathrm{sec})$ than what would be predicted from the washout $(\sim 10 \mathrm{sec})$ and from the time necessary for equilibration by diffusion of caffeine between the extracellular space and the cytoplasm [ 1 sec (Lipscombe et al., 1988; O’Neill et al., 1990; Friel and Tsien, 1992)]; (2) the fall of $\left[\mathrm{Ca}^{2+}\right]_{\mathrm{i}}$ from the transient peak was much more rapid for larger excursions from the baseline (Fig. $3)$; (3) similar depressions in $\left[\mathrm{Ca}^{2+}\right]_{i}$ were observed after spontaneous regenerative spikes in $\operatorname{rod}\left[\mathrm{Ca}^{2+}\right]_{i}$ (Fig. 10) in the absence of caffeine; (4) depressions in $\left[\mathrm{Ca}^{2+}\right]_{i}$ were observed with 4-chloro- $m$-cresol and thymol, two nonxanthine compounds known to release $\mathrm{Ca}^{2+}$ from caffeine-sensitive stores (Zorzato et al., 1993; Cseresnyes et al., 1997); and (5) the depression was substantially reduced by substitution of $\mathrm{Ca}^{2+}$ by $\mathrm{Ba}^{2+}$.
The caffeine-evoked depression of $\left[\mathrm{Ca}^{2+}\right]_{i}$ is also unlikely to result from an inhibitory action of caffeine on a phosphodiesterase that reduces intracellular cyclic nucleotides. We found that exposure to caffeine did not markedly affect either the membrane potential or the light responses of dark-adapted rods. This strongly suggests that the cGMP-dependent phosphodiesterases in rod outer segments were not inhibited significantly by $10 \mathrm{~mm}$ caffeine. Furthermore, we found that $100 \mu \mathrm{M}$ IBMX, a dose that should block PDEs, did not affect release of $\mathrm{Ca}^{2+}$ from caffeinesensitive channels (Capovilla et al., 1983; Cervetto and McNaughton, 1986; Cseresnyes et al., 1997) and had no effect on the steady-state $\left[\mathrm{Ca}^{2+}\right]_{\mathrm{i}}$ in rods $(n=6)$. It should be noted that our findings contrast to a previous report by Capovilla et al. (1983) in which $0.3 \mathrm{~mm}$ caffeine increased the amplitude of rod light responses in toad. Finally, the experiments with $4-\mathrm{CmC}(0.5 \mathrm{~mm})$ and thymol $(0.1 \mathrm{~mm})$, two nonxanthine compounds not known to interfere with phosphodiesterases, mimicked caffeine by generating a depression of $\left[\mathrm{Ca}^{2+}\right]_{i}$.

Voltage-clamp and microelectrode recordings eliminate the possibility that caffeine depressed $\left[\mathrm{Ca}^{2+}\right]_{i}$ by activating $\mathrm{Ca}^{2+}$ dependent conductances that hyperpolarized the rods to decrease the activation of the L-type calcium channels and hence calcium influx (Akaike et al., 1983; Sah and McLachlan, 1991; Marrion and Adams, 1992; Sridhar et al., 1996). Salamander rods possess calcium-activated chloride and potassium conductances (Bader et al., 1982). Although these conductances may have increased after caffeine-mediated release of $\mathrm{Ca}^{2+}$ from the stores, they could not have contributed significantly to the reduction in $I_{\mathrm{Ca}}$ that persisted under voltage clamp (Fig. 8). Moreover, intracellular recording from rods showed no effect of caffeine on rod membrane potential, whereas both glutamate release and horizontal cell membrane potential were markedly depressed under those conditions (Figs. 5, 6). This indicates that a change in the rod membrane potential is not likely to be responsible for generating the depression.

Yet another explanation might be proposed that caffeine suppresses the $\mathrm{IP}_{3}$ receptor on the inner segment ER (Peng et al., 1991; Ehrlich et al., 1994) and thus inhibits a possible depolarization-activated tonic $\mathrm{IP}_{3}$-gated release of $\mathrm{Ca}^{2+}$ (Gan and Iuvone, 1997). However, an effect similar to that of caffeine was obtained with nonxanthine compounds, such as $4-\mathrm{CmC}$, that are not thought to inhibit $\mathrm{IP}_{3}$ receptors.

\section{A release-activated stimulation of calcium uptake or extrusion likely contributes to caffeine-evoked depression of $\left[\mathrm{Ca}^{2+}\right]_{i}$}

It has been postulated that caffeine-induced calcium release from stores stimulates calcium uptake into ER or into mitochondria (Friel and Tsien, 1992; Orkand and Thomas, 1995; Cseresnyes et al., 1997; Lara et al., 1997; Golovina and Blaustein, 1998). Our finding that $1 \mathrm{~mm}$ caffeine slightly potentiated glutamate release whereas $10 \mathrm{~mm}$ caffeine inhibited it is similar to a previous report on the effect of caffeine on $\left[\mathrm{Ca}^{2+}\right]_{\mathrm{i}}$ in sympathetic neurons (Friel and Tsien, 1992). Friel and Tsien were the first to propose that "depending on its $\mathrm{Ca}^{2+}$ content, the caffeine-sensitive store can either attenuate or potentiate responses to depolarization.” Recently, Cseresnyes et al. (1997) reported that in sympathetic neurons caffeine greatly potentiates calcium removal from the cytosol. After being triggered by caffeine-induced release, this mechanism continues removing calcium from the cytosol, resulting in a substantial lowering of $\left[\mathrm{Ca}^{2+}\right]_{\mathrm{i}}$. Our findings in rods that caffeine evokes a depression of $\left[\mathrm{Ca}^{2+}\right]_{i}$ to values well below 
prestimulus levels and that the falling phase of the caffeineevoked $\mathrm{Ca}^{2+}$ signal is faster (Fig. 3) are consistent with releasestimulated sequestration or extrusion.

\section{Why did ryanodine not completely eliminate the decreases in $\left[\mathrm{Ca}^{2+}\right]_{i}$ and glutamate release?}

In isolated cells, ryanodine eliminated caffeine-induced increases in $\left[\mathrm{Ca}^{2+}\right]_{i}$, consistent with its action as a blocker of the ryanodine receptor. Ryanodine also reduced the caffeine-mediated decrease in $\left[\mathrm{Ca}^{2+}\right]_{\mathrm{i}}$ and $I_{\mathrm{Ca}}$, suggesting that at least part of the undershoot in $\left[\mathrm{Ca}^{2+}\right]_{\mathrm{i}}$ and glutamate release is mediated by $\mathrm{Ca}^{2+}$ release from ryanodine-gated channels. The finding that ryanodine did not completely block the $\left[\mathrm{Ca}^{2+}\right]_{\mathrm{i}}$ undershoot suggests that at least part of the $\mathrm{Ca}^{2+}$ release, activated by caffeine, may be from another, ryanodine-insensitive, class of calcium stores, similar to those described in several other cell types (Marrion and Adams, 1992; McNulty and Taylor, 1993; Orkand and Thomas, 1995; Pessah et al., 1997). This release may be missed by the global fura-2 measurements yet significant enough to evoke a depression in $\left[\mathrm{Ca}^{2+}\right]_{\mathrm{i}}$ (e.g., Fig. 4). Surprisingly, ryanodine had no effect on the caffeine-mediated reduction of glutamate release. Possibly this result was a consequence of poor tissue permeability of ryanodine, as has been hypothesized for tissue slices (Llano et al., 1995). Consistent with this interpretation of poor tissue penetration was the observation that even the caffeine effect on horizontal cell potential was somewhat delayed.

\section{The role of calcium stores in the regulation of transmitter release from rods}

Our results demonstrate that intracellular stores in rods are capable of storing significant amounts of calcium. This finding complements the cytochemical and EM studies that localized the highest concentrations of calcium in amphibian and teleost rods to the inner segment ER (Mercurio and Holtzman, 1982; Ungar et al., 1984; Somlyo and Walz, 1985). Our finding that the pool size of caffeine-releasable intracellular calcium depends on the basal levels of $\left[\mathrm{Ca}^{2+}\right]_{\mathrm{i}}$ suggests that the participation of calcium stores in synaptic signaling will be more significant in darkness, when $\left[\mathrm{Ca}^{2+}\right]_{\mathrm{i}}$ is high (Ratto et al., 1988; Gray-Keller and Detwiler, 1994), than in the light, when inner segment $\left[\mathrm{Ca}^{2+}\right]_{\mathrm{i}}$ drops to levels as low as 20-50 nm (Krizaj and Copenhagen, 1998). In vivo, calcium is released from ryanodine-sensitive stores by cytosolic calcium, by a process termed calcium-induced calcium release. The concentration range over which calcium activates the ryanodine receptor, an approximately sigmoidal activation by $\mathrm{Ca}^{2+}$ at concentrations between $10 \mathrm{nM}$ and $10 \mu \mathrm{M}$ (Bezprozvanny et al., 1991; Hernandez-Cruz et al., 1995), indicates that calcium stores in rod inner segments and synaptic terminals could be activated in both dark and light.

In darkness, steady influx of $\mathrm{Ca}^{2+}$ through the L-type $\mathrm{Ca}^{2+}$ channels (Rieke and Schwartz, 1996) would trigger $\mathrm{Ca}^{2+}$ release from the stores. The high density of ryanodine receptors, the long open times and high single-channel conductances of ryanodine receptor-gated channels [100 to $\sim 400$ pS (Bezprozvanny et al., 1991; Hernandez-Cruz et al., 1995)], and the close proximity of $\mathrm{Ca}^{2+}$ stores to the plasma membrane (Sridhar et al., 1996; Sham, 1997) would create a local negative feedback loop. $\mathrm{Ca}^{2+}$ released from the stores would inactivate the L-type channels and thus reduce calcium influx. The resulting depression of $\left[\mathrm{Ca}^{2+}\right]_{i}$ is accompanied by facilitation of $\mathrm{Ca}^{2+}$ uptake into the stores (Orkand and Thomas, 1995; Cseresnyes et al., 1997; Lara et al., 1997). Thus, the compounded action of $\mathrm{Ca}^{2+}$-induced inactiva- tion of $\mathrm{Ca}^{2+}$ channels and enhancement of calcium uptake would result in a reduced $\left[\mathrm{Ca}^{2+}\right]_{\mathrm{i}}$ and a reduction of transmitter release. Conversely, in the light, when $\mathrm{Ca}^{2+}$ channels are closed and the $\mathrm{Ca}^{2+}$ influx is low, the stores would be relatively quiescent, and each $\mathrm{Ca}^{2+}$ ion would be proportionally more efficient in triggering release of vesicles filled with glutamate. The stores could therefore act as a negative feedback regulator, increasing the dynamic range of the synapse via its control of $\left[\mathrm{Ca}^{2+}\right]_{i}$ and transmitter release.

\section{REFERENCES}

Adachi-Akahane S, Cleeman L, Morad M (1996) Cross-signaling between L-type $\mathrm{Ca}^{2+}$ channels and ryanodine receptors in rat ventricular myocytes. J Gen Physiol 108:435-454.

Akaike N, Brown AM, Dahl G, Higashi H, Isenberg G, Tsuda Y, Yatani A (1983) Voltage-dependent activation of potassium current in Helix neurones by endogenous cellular calcium. J Physiol (Lond) 334:309-324.

Bader CR, MacLeish PR, Schwartz EA (1979) A voltage-clamp study of the light response in solitary rods of the tiger salamander. J Physiol (Lond) 296:1-26.

Bader CR, Bertrand D, Schwartz EA (1982) Voltage-activated and calcium-activated currents studied in solitary rod inner segments from the salamander retina. J Physiol (Lond) 331:253-284.

Barnes S, Hille B (1989) Ionic channels of the inner segment of tiger salamander cone photoreceptors. J Gen Physiol 94:719-743.

Berridge MJ (1998) Neuronal calcium signaling. Neuron 21:13-26.

Bezprozvanny I, Watras J, Ehrich BE (1991) Bell-shaped calciumresponse curves of Ins(1,4,5)P3- and calcium-gated channels from endoplasmic reticulum of cerebellum. Nature 351:751-754. J Physiol (Paris) $76: 459-470$.

Cahill GM, Besharse JC (1992) Light-sensitive melatonin synthesis by Xenopus photoreceptors after destruction of the inner retina. Vis Neurosci 8:487-490.

Capovilla M, Cervetto L, Torre V (1983) The effect of phosphodiesterase inhibitors on the electrical activity of toad rods. J Physiol (Lond) 343:277-294.

Cervetto L, McNaughton PA (1986) The effects of phosphodiesterase inhibitors and lanthanum ions on the light-sensitive current of toad retinal rods. J Physiol (Lond) 370:91-109.

Cheek TR, O'Sullivan AJ, Moreton RB, Berridge MJ, Burgoyne RD (1990) The caffeine-sensitive $\mathrm{Ca}^{2+}$ store in bovine adrenal chromaffin cells; an examination of its role in triggering secretion and $\mathrm{Ca}^{2+}$ homeostasis. FEBS Lett 266:91-95.

Copenhagen DRC, Jahr CE (1989) Release of endogenous excitatory amino acids from turtle photoreceptors. Nature 341:536-539.

Corey DP, Dubinsky JM, Schwartz EA (1984) The calcium current in inner segments of rods from the salamander (Ambystoma tigrinum) retina. J Physiol (Lond) 354:557-575.

Cseresnyes Z, Bustamante AI, Klein MG, Schneider MF (1997) Release-activated $\mathrm{Ca}^{2+}$ transport in neurons of frog sympathetic ganglia. Neuron 19:403-419.

de Leon M, Wang Y, Jones L, Perez-Reyes E, Wei X, Soong TW, Snutch T, Yue D (1995) Essential $\mathrm{Ca}^{2+}$-binding motif for $\mathrm{Ca}^{2+}$-sensitive inactivation of L-type $\mathrm{Ca}^{2+}$ channels. Science 270:1502-1506.

Ehrlich BE, Kaftan E, Bezprozvannaya S, Bezprozvanny I (1994) The pharmacology of intracellular $\mathrm{Ca}^{2+}$-release channels. Trends Pharmacol Sci 15:145-149.

Fain GL (1976) Sensitivity of toad rods: dependence on wave-length and background illumination. J Physiol (Lond) 261:71-101.

Fosse VM, Kolstad J, Fonnum F (1986) A bioluminescence method for measurement of L-glutamate: applications to the study of changes in release of L-glutamate from lateral geniculate nucleus and superior colliculus after visual ablation in rats. J Neurochem 47:340-349.

Friel DD, Tsien RW (1992) A caffeine- and ryanodine-sensitive $\mathrm{Ca}^{2+}$ store in bullfrog sympathetic neurones modulates effects of $\mathrm{Ca}^{2+}$ entry on $\left[\mathrm{Ca}^{2+}\right]$ i. J Physiol (Lond) 450:217-246.

Gabriel R, Akopian A, Witkovsky P (1998) Co-localization of ryanodine- and inositol triphosphate receptors in retinal ganglion cells. IOVS Suppl 39:4564.

Gan J, Iuvone PM (1997) Depolarization and activation of dihydropyridine-sensitive $\mathrm{Ca}^{2+}$ channels stimulate inositol phosphate 
accumulation in photoreceptor-enriched chick retinal cell cultures. J Neurochem 68:2300-2307.

Garaschuk O, Yaari Y, Konnerth A (1997) Release and sequestration of calcium by ryanodine-sensitive stores in rat hippocampal neurones. J Physiol (Lond) 502:13-30.

Golovina VA, Blaustein MP (1998) Spatially and functionally distinct $\mathrm{Ca}^{2+}$ stores in sarcoplasmic and endoplasmic reticulum. Science 275:1643-1648.

Gray-Keller MP, Detwiler PB (1994) The calcium feedback signal in the phototransduction cascade of vertebrate rods. Neuron 13:849-861.

Grzynkiewicz G, Poenie M, Tsien RY (1985) A new generation of Ca indicators with greatly improved fluorescence properties. J Biol Chem 260:3440-3450.

Haack JA, Rosenberg RL (1994) Calcium-dependent inactivation of L-type calcium channels in planar lipid bilayers. Biophys $\mathrm{J}$ 66:1051-1060.

Henkart ML, Landis DMD, Reese TS (1976) Similarity of junctions between plasma membrane and endoplasmic reticulum in muscle and neurons. J Cell Biol 70:338-347.

Hernandez-Cruz A, Diaz-Muñoz M, Gomez-Chavarin M, CañedoMerino R, Protti DA, Escobar AL, Sierralta J, Suarez-Isla BA (1995) Properties of the ryanodine-sensitive release channels that underlie caffeine-induced $\mathrm{Ca}^{2+}$ mobilization from intracellular stores in mammalian sympathetic neurons. Eur J Neurosci 7:1684-1699.

Hua SY, Nohmi M, Kuba K (1993) Characteristics of $\mathrm{Ca}^{2+}$ release induced by $\mathrm{Ca}^{2+}$ influx in cultured bullfrog sympathetic neurones. J Physiol (Lond) 464:245-272.

Hughes A, Hering S, Bolton TB (1990) The action of caffeine on inward barium current through voltage-dependent calcium channels in single rabbit ear artery cells. Pflügers Arch 416:462-466.

Katz B, Miledi R (1969) Tetrodotoxin-resistant electrical activity in presynaptic terminals. J Physiol (Lond) 203:459-487.

Kramer RH, Mokkapatti R, Levitan ES (1994) Effects of caffeine on intracellular calcium, calcium current and calcium-dependent potassium current in anterior pituitary GH3 cells. Pflügers Arch 426:12-20.

Krijnse-Locker J, Parton RG, Fuller SD, Griffiths G, Dotti CG (1995) The organization of the endoplasmic reticulum and the intermediate compartment in cultured rat hippocampal neurones. Mol Biol Cell 6:1315-1332.

Krizaj D, Copenhagen DR (1998) Compartmentalization of calcium extrusion in the outer and inner segments of vertebrate photoreceptors. Neuron 21:249-256.

Krizaj D, Akopian A, Witkovsky P (1994) The effects of L-glutamate, AMPA, quisqualate, and kainate on retinal horizontal cells depend on adaptational state: implications for rod-cone interactions. J Neurosci 14:5661-5671.

Krizaj D, Bao JX, Copenhagen DR (1997) Intracellular calcium stores in vertebrate rods and cones. Soc Neurosci Abstr 23:2360.

Kwan CY, Putney JW (1990) Uptake and intracellular sequestration of divalent cations in resting and methacholine-stimulated mouse lacrimal acinar cells. Dissociation by $\mathrm{Sr}^{2+}$ and $\mathrm{Ba}^{2+}$ of agonist-stimulated divalent cation entry from the refilling of the agonist-sensitive intracellular pool. J Biol Chem 265:678-684.

Lara B, Lopez MG, Villaroya M, Gandia L, Cleeman L, Morad M, Garcia AG (1997) A caffeine-sensitive Ca store modulates $\mathrm{K}^{+}$-evoked secretion in chromaffin cells. Am J Physiol 272:C1211-C1221.

Lipscombe D, Madison DV, Poenie M, Reuter H, Tsien RY, Tsien RW (1988) Spatial distribution of calcium channels and cytosolic calcium transients in growth cones and cell bodies of sympathetic neurons. Proc Natl Acad Sci USA 85:2398-2402.

Llano I, DiPolo R, Marty A (1995) Calcium-induced calcium release in cerebellar Purkinje cells. Neuron 12:663-673.

MacLeish P, Barnstable CJ, Townes-Anderson E (1983) Use of a monoclonal antibody as a substrate for mature neurons in vitro. Proc Natl Acad Sci USA 80:7014-7018.

Marrion NV, Adams PR (1992) Release of intracellular calcium and modulation of membrane currents by caffeine in bullfrog sympathetic neurones. J Physiol (Lond) 445:515-535.

Matthews G (1997) Neurotransmitter release. Annu Rev Neurosci 19:219-233.

McNulty TJ, Taylor CW (1993) Caffeine-stimulated $\mathrm{Ca}^{2+}$ release from the intracellular stores of hepatocytes is not mediated by ryanodine receptors. Biochem J 291:799-801.
McPherson PS, Kim YK, Valdivia H, Knudson CM, Takekura H, Franzini-Armstrong C, Coronado R, Campbell KP (1991) The brain ryanodine receptor: a caffeine-sensitive calcium release channel. Neuron $7: 17-25$.

Meldolesi J, Pozzan T (1998) The endoplasmic reticulum: a view from the lumen. Trends Biochem Sci 23:10-14.

Mercurio AM, Holtzman E (1982) Smooth endoplasmic reticulum and other agranular reticulum in frog retinal photoreceptors. J Neurocytol 11:263-293.

Minke B, Selinger Z (1996) The roles of trp and calcium in regulating photoreceptor function in Drosophila. Curr Opin Neurobiol 6:459-466.

Neher E (1995) The use of fura-2 for estimating Ca buffers and Ca fluxes. Neuropharmacology 34:1423-1442.

Neher E (1998) Vesicle pools and $\mathrm{Ca}^{2+}$ microdomains: new tools for understanding their roles in neurotransmitter release. Neuron 20:389-399.

Nehlig A, Daval JL, Debry G (1992) Caffeine and the central nervous system: mechanisms of action, biochemical, metabolic and psychostimulant effects. Brain Res Rev 17:139-170.

O'Neill SC, Donoso P, Eisner DA (1990) The role of $\left[\mathrm{Ca}^{2+}\right] \mathrm{i}$ and $\left[\mathrm{Ca}^{2+}\right]$ sensitization in the caffeine contracture of rat myocytes: measurement of $\left[\mathrm{Ca}^{2+}\right] \mathrm{i}$ and [caffeine]i. J Physiol (Lond) 425:55-70.

Orkand RK, Thomas RC (1995) Effects of low doses of caffeine on $\left[\mathrm{Ca}^{2+}\right] \mathrm{i}$ in voltage-clamped snail (Helix aspersa) neurones. J Physiol (Lond) 489:19-28.

Pacaud P, Loirand G, Mironneau C, Mironneau J (1987) Opposing effects of noradrenaline on the two classes of voltage-dependent calcium channels of single vascular smooth muscle cells in short term primary culture. Pflügers Arch 410:557-559.

Peng YW, Sharp AH, Snyder SH, Yau KW (1991) Localization of the inositol 1,4,5-triphosphate receptor in synaptic terminals in the vertebrate retina. Neuron 6:525-531.

Pessah IN, Molinski TF, Meloy TD, Wong P, Buck ED, Allen PD, Mohr FC, Mack MM (1997) Bastadins relate ryanodine-sensitive and -insensitive $\mathrm{Ca}^{2+}$ efflux pathways in skeletal SR and BC3H1 cells. Am J Physiol 272:C601-C614.

Pozzan T, Rizzuto R, Volpe P, Meldolesi J (1994) Molecular and cellular physiology of intracellular calcium stores. Physiol Rev 74:595-636.

Przywara DA, Chowdhury PS, Bhave SV, Wakade TD, Wakade AR (1993) Barium-induced exocytosis is due to internal calcium release and block of calcium efflux. Proc Natl Acad Sci USA 90:557-561.

Ratto GM, Payne R, Owen WG, Tsien RY (1988) The concentration of cytosolic free calcium in vertebrate rod outer segments measured with fura-2. J Neurosci 8:3240-3246.

Rieke F, Schwartz EA (1996) Asynchronous transmitter release: control of exocytosis and endocytosis at the salamander rod synapse. J Physiol (Lond) 493:1-8.

Sah P, McLachlan EM (1991) $\mathrm{Ca}^{2+}$-activated $\mathrm{K}^{+}$currents underlying the afterhyperpolarization in guinea pig vagal neurons: a role for $\mathrm{Ca}^{2+}$-activated $\mathrm{Ca}^{2+}$ release. Neuron 7:257-264.

Schilling WP, Rajan L, Strobl-Jager E (1989) Characterization of the bradykinin-stimulated calcium influx pathway of cultured vascular endothelial cells. J Biol Chem 264:12838-12848.

Schmid A, Dehlinger-Kremer M, Schulz I, Gogelein H (1990) Voltagedependent Ins3-insensitive calcium channels in membranes of pancreatic endoplasmic reticulum vesicles. Nature 346:374-376.

Schmitz Y, Witkovsky P (1996) Glutamate release by the intact lightresponsive photoreceptor layer of the Xenopus retina. J Neurosci Methods 68:55-60.

Schmitz Y, Witkovsky P (1997) Dependence of photoreceptor glutamate release on a dihydropyridine-sensitive calcium channel. Neuroscience 78:1209-1216.

Schumann K, Romanin C, Baumgartner W, Groschner K (1997) Intracellular $\mathrm{Ca}^{2+}$ inhibits smooth muscle L-type $\mathrm{Ca}^{2+}$ channels by activation of protein phosphatase type $2 \mathrm{~B}$ and by direct interaction with the channel. J Gen Physiol 110:503-513.

Sham JSK (1997) $\mathrm{Ca}^{2+}$ release-induced inactivation of $\mathrm{Ca}^{2+}$ current in rat ventricular myocytes: evidence for local $\mathrm{Ca}^{2+}$ signalling. J Physiol (Lond) 500:285-295.

Sitsapesan R, Williams AJ (1990) Mechanisms of caffeine activation of single calcium-release channels of sheep cardiac sarcoplasmic reticulum. J Physiol (Lond) 423:425-439.

Somlyo AP, Walz B (1985) Elemental distribution in Rana pipiens retinal rods: quantitative electron probe analysis. J Physiol (Lond) 358: 183-195. 
Sridhar TS, Brown MC, Sewell WF (1996) Unique postsynaptic signaling at the hair cell efferent synapses permits calcium to evoke changes on two time scales. J Neurosci 17:428-437.

Tse FW, Tse A, Hille B, Horstmann H, Almers W (1997) Local Ca ${ }^{2+}$ release from internal stores controls exocytosis in pituitary gonadotrophs. Neuron 18:121-132.

Tsien RW, Lipscombe D, Madison DV, Bley KR, Fox AP (1988) Multiple types of neuronal calcium channels and their selective modulation. Trends Neurosci 11:431-438.

Tsien RY (1980) New calcium indicators and buffers with high selectivity against magnesium and protons: design, synthesis and properties of prototype structures. Biochemistry 19:2396-2404.

Ungar F, Piscopo I, Letizia J, Holtzman E (1984) Uptake of calcium by the endoplasmic reticulum of the frog photoreceptor. J Cell Biol 98:1645-1655.

Walton PD, Airey JA, Sutko JL, Beck CF, Mignery GA, Südhof TC, Deerinck TJ, Ellisman MH (1991) Ryanodine and inositol triphosphate receptors coexist in avian cerebellar Purkinje neurons. J Cell Biol 113:1145-1157.

Witkovsky P, Schmitz Y, Akopian A, Krizaj D, Tranchina D (1997) Gain of rod to horizontal cell synaptic transfer: relation to glutamate release and a dihydropyridine-sensitive calcium current. J Neurosci 17:7297-7306.

Zorzato F, Scutari E, Tegazzin V, Clementi E, Treves S (1993) Chlorocresol: an activator of ryanodine receptor-mediated $\mathrm{Ca}^{2+}$ release. Mol Pharmacol 44:1192-1201. 